\title{
放射性廃棄物の地下空洞型処分施設に用いる 底部低透水層の転圧エ法による施工品質の評価
}

\author{
山田 淳夫 1 -千々松 正和 2 - 藤原 斉郁 3 - 矢田 勤 4 ・ \\ 秋山 吉弘 5 ・ 小峯 秀雄 6 ・飯塚 敦7 \\ 1正会員 公益財団法人原子力環境整備促進・資金管理センター（テ104-0052 東京都中央区月島1-15-7） \\ E-mail: atsuo.yamada@rwmc.or.jp \\ 2正会員＼cjkstart株式会社安藤・間（†305-0822 茨城県つくば市苅間515-1） \\ E-mail: chijimatsu.masakazu@ad-hzm.co.jp \\ 3正会員大成建設株式会社＼cjkstart技術センター（†245-0051 横浜市戸塚区名瀬町344-1） \\ E-mail: tadafumi.fujiwara@sakura.taisei.co.jp \\ 4正会員 大成建設株式会社＼cjkstart東北支店土木部（干980-0811 仙台市青葉区一番町3-1-1） \\ E-mail: yada2106@ce.taisei.co.jp \\ 5正会員 公益財団法人原子力環境整備促進・資金管理センター（†104-0052 東京都中央区月島1-15-7） \\ E-mail: akiyama@rwmc.or.jp \\ 6正会員 早稲田大学教授 理工学術院創造理工学部社会環境工学科 \\ （干169-8555 東京都新宿区大久保3-4-1） \\ E-mail: hkomine@waseda.jp \\ 7 正会員 神戸大学教授 自然科学系先端融合研究環 都市安全研究センター \\ （三657-8501 神戸市灘区六甲台町1-1） \\ E-mail: iizuka@kobe-u.ac.jp
}

\begin{abstract}
低レベル放射性廃棄物のうち比較的放射能レベルの高い放射性廃棄物を対象とする余裕深度処分では, ベントナイトで構成される低透水層は人工バリアとして重要な機能を期待されている。この低透水層の設 計や施工方法の検討にあたり, 地下空洞内において実規模で実際に施工を行い，施工のしやすさ，実現性 の確認と低透水性等の性能の確認を行うことは重要である。そこで, ベントナイトを用いた底部低透水層 を対象とした，施工試験と室内試験による性能確認試験を実施した。その結果，施工のしやすさ，実現性 を確認するとともに, 施工後の品質として低透水層に求められる透水係数をはじめとする性能が確保可能 なことを確認した.
\end{abstract}

Key Words : subsurface disposal, engineered barrier, bentonite, vibrating compaction, permeability, dry density

\section{1. はじめに}

低レベル放射性廃棄物の余裕深度処分の方法として， 地下にトンネルを掘削し処分施設を設置する地下空洞型 処分施設の検討が行われている1). 余裕深度処分とは, 地下利用に十分余裕をもった深度（表層から50～ 100m）に廃棄物を処分するものである。これまで余裕 深度処分施設の設計と品質管理の考え方は, 土木学会2) 等により検討されており，図-1に示したような施設構成 が検討されている。
施設は要求機能に応じた複数の部材で構成されており, 廃棄体，コンクリートピット，低拡散層およびこれらを 包み込むように低透水層が配置される計画である. 本論 文では，このうち底盤部分に設置される底部低透水層を 対象としている.

この処分場概念では，低透水層としてベントナイトを 使用することとなっている，これは，諸外国はもとより， 日本の高レベル放射性廃暂物処分の研究でも取り扱われ ていない材料である。これまで，主に圧縮成型した供試 体を用いた室内試験による透水性や力学特性に関する検 


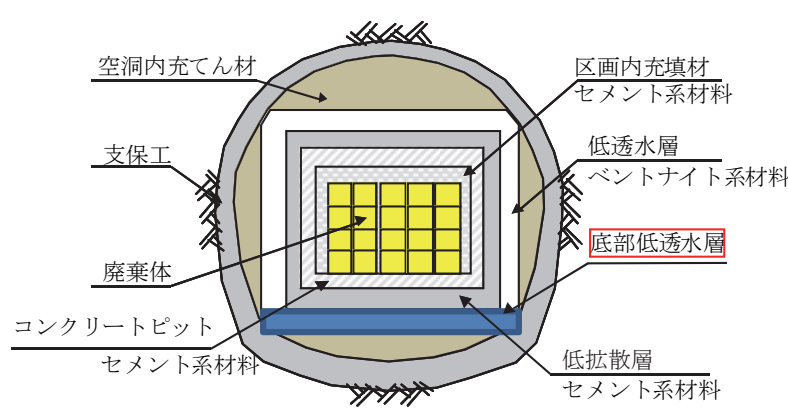

図-1 地下空洞型処分施設構成 (土木学会2)より一部改変)

討が行われてきたが，地下空洞の環境下でこの材料を用 いて高品質の低透水層を構築する施工方法の確立と施工 後の品質の確認が重要となってきた．底部低透水層の施 設特有の施工条件に関する課題として，低透水性（透水 係数で $\left.5 \times 10^{-13} \mathrm{~m} / \mathrm{s}\right)$ を満足する高品質な底部低透水層の 施工，すなわち粒状ベントナイト $100 \%$ の材料を大型機 械によって撒出し・敷均しおよび転圧し，極めて低透水 の層を構築することが可能なのかを確認する必要があっ た. これらの課題に対して地下空洞を利用した実規模施 工試験，および施工後の低透水層から採取した試料を用 いた室内試験によって, 品質を検討した.

\section{2. 底部低透水層の概要と課題}

余裕深度処分施設の部材毎の要求機能は表-12)に示し たとおり，土木学会”によりまとめられている. ベント ナイト系材料で構築される低透水層の要求機能は, 建設 操業段階においては，放射性核種の「閉じ込め」および

「操業上の機能」のうち「確実な建設, 操業が行われる 空間, 力学的安定性が確保されること」（以下，力学的 安定性の確保）であり，埋戻し後の放射性核種の「移行 抑制」である. これらの要求機能を確保するために求め られる技術要件は，「閉じ込め」「移行抑制」に対する ものとして「透水特性」があり，操業段階の力学的安定 性確保に対するものとして「力学特性」がある2!.

「透水特性」に関する技術的な要件は透水性が低いこ とが求められ，これにより，水とともに移動する放射性 核種の移行速度を低くすることが期待されている.

「力学特性」に関する技術的な要件は，不飽和状態に おけるある程度以上の強度が求められている。 これは, 底部低透水層を構築した後の工程で, 図-1に示したよう に，コンクリートピットの構築，廃棄体の定置，区画内 充填材の充てん，低拡散層の構築とが行われる.これら の構造物が底部緩衝材一の上載荷重となるため，この上 載荷重に対して圧壊せず安定することが求められる。こ のような力学的な安定性の問題は, その後に構築される 側部・上部低透水層，および空洞内充てん材が構築され
表-1 低透水層の要求機能2)

\begin{tabular}{|c|c|c|c|c|}
\hline \multicolumn{2}{|c|}{ 要求機能 } & 段 & 機能の内容 & $\begin{array}{l}\text { 機能 } \\
\text { の } \\
\text { 要否 }\end{array}$ \\
\hline \multirow{8}{*}{ 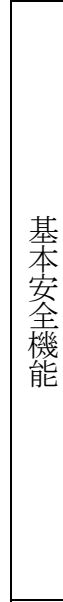 } & $\begin{array}{l}\text { 閉じ } \\
\text { 込め }\end{array}$ & \multirow{2}{*}{ 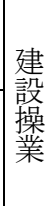 } & $\begin{array}{l}\text { 放射線物質の埋設施設外の環境への } \\
\text { 有意な漏洩を防止すること }\end{array}$ & $\bullet$ \\
\hline & $\begin{array}{l}\text { 遮へ } \\
\text { W }\end{array}$ & & $\begin{array}{l}\text { 廃棄体を線源とする放射線に対し } \\
\text { て, 十分な遮へいを有する環境を保 } \\
\text { つこと }\end{array}$ & - \\
\hline & \multirow{4}{*}{$\begin{array}{l}\text { 移行 } \\
\text { 抑制 }\end{array}$} & \multirow{6}{*}{ 埋 } & $\begin{array}{l}\text { 放射性核種の拡散による移動を抑制 } \\
\text { すること }\end{array}$ & - \\
\hline & & & 放射性核種を収着すること & - \\
\hline & & & $\begin{array}{l}\text { 低透水性により，処分施設を通過す } \\
\text { る地下水流量の抑制を行うこと }\end{array}$ & • \\
\hline & & & $\begin{array}{l}\text { 連続した地下水移行経路を形成しな } \\
\text { いこと }\end{array}$ & - \\
\hline & \multirow{2}{*}{ 離隔 } & & 離隔距離を確保すること & - \\
\hline & & & 容易な侵入を防止すること & - \\
\hline \multirow{2}{*}{\multicolumn{2}{|c|}{ 操業上の }} & \multirow{2}{*}{ 建 } & $\begin{array}{l}\text { 確実な建設, 操業が行われる空間, } \\
\text { 力学的安定性が確保されること }\end{array}$ & 0 \\
\hline & & & 坑道の形状を維持すること & - \\
\hline
\end{tabular}

ていくことで，次第に岩盤と一体化し，拘束されて変位 しにくくなることにより, 安定していくと考えられる. すなわち, 底部低透水層においては強度も重要となる。

このような機能を有する底部低透水層を構築するため には，十分に高密度に締め固められることが必要と考え られる。

底部低透水層の施工上の課題は，土質材料の転圧によ る締固め施工と同様の課題が挙げられる. すなわち, 材 料の含水比の調整，材料の撒出し・敷均し，転圧時の締 固め性である. また, 施工後の品質が, 要求される性能 を満足するものであるのかを確認する必要がある。これ らの課題について, 以下に詳述する.

\section{（1） 材料の含水比の調整}

底部低透水層の候補材料はベントナイトである. ベン トナイトも通常の土質材料のように, 締固め後の乾燥密 度と含水比との間には相関関係があり, 締固め曲線でそ の関係が表される.この締固め曲線から得られる最適含 水比よりも湿潤側の含水比で透水係数が最も小さくなる ため，低透水性を求められる場合には，そのような含水 比で施工されることが多い，一方，ベントナイトを施工 する時の含水比は，施工性や仕上り密度のばらつきに密 接に関連することがこれまでの知見で得られており，層 内の密度差を低減させるため, 材料の含水比のばらつき を抑制することが一つの方策であると考えられる ${ }^{3)}$.

転圧時の締固めエネルギーが常に一定であったとして も, 含水比のばらつきにより, 締固め後の乾燥密度もば らつく. すなわち, 品質のばらつきの少ない低透水層を 
構築するためには，使用する材料の含水比が均一になる ように調整を行う必要がある。

\section{(2) 材料の撒出し・敷均し}

材料の撒出し・敷均しが粗密で不均一であれば，その 後工程でも粗密で不均一に締め固められ, 転圧後の乾燥 密度にばらつきが生じる恐れがある，そのため，材料の 撒出し・敷均しを均一に行うことは重要である.しかし， 底部低透水層の候補材料であるベントナイトを後述のよ うな大型施工機械で撒出し・敷均しを実施した事例は少 ないため，実際に施工して確認する必要がある.

\section{（3）転圧時の施工性・締固め性}

ベントナイトを施工機械を用いて実際に転圧し，施工 性・締固め性を確認する必要がある，また，施工機械の 能力が高くても，材料自体が締固め性が悪い場合がある. これは先述の含水比の他にもコンシステンシー, 粒度分 布といった材料自体の特性が関連しているためである ${ }^{4}$. そのため, 転圧機械による締固めに最適な材料を選定す る必要があり, 選定した材料・機械・工法を用いて実際 に施工を行い確認する必要がある。

\section{（4）施工後の品質確認}

実際に施工した底部低透水層が，要求機能を確保でき る技術要件を満たしているのかを確認する必要がある.

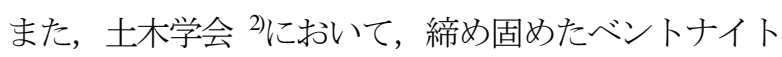
系材料の乾燥密度と透水係数および乾燥密度と膨潤圧と の相関性が示されている。このような相関性は，施工後 に乾燥密度を測定すれば暫定的に品質を把握することが できるため，有用である。しかし，これらの相関性は， 主に室内で圧縮成型した供試体を用いた試験結果より得 られたものである. そのため, このような乾燥密度との 相関性が，実際に施工された低透水層から採取した試料 でも成立するのかを確認する必要がある.

以上のように，底部低透水層には施工上の課題（材料 の含水比の調整，材料の撒出し・敷均し，転圧時の締固 め性）および施工後の品質確認に関する課題がある。こ れらの課題に対して，本論文での検討項目と実施内容を 表-2に示す. それらについて次節以降で説明する.

\section{3. 材料の選定と要求機能を満たす目標值の設定}

低透水層の要求機能を満足するための主な技術要件の 一つは, 先述のとおり「透水特性」であり, 低透水性が 求められる. 本論文で扱っている地下空洞型処分施設と 基本構成が類似した TRU 廃棄物地層処分施設を対象と した既往の検討では，緩衝材内部の物質移行が拡散支配
表-2 本論文の検討項目と実施内容

\begin{tabular}{|c|c|c|}
\hline \multicolumn{2}{|r|}{ 検討項目 } & 実施内容 \\
\hline (1) & $\begin{array}{l}\text { 材料の選定 } \\
\text { と要求機能 } \\
\text { を満たす目 } \\
\text { 標値の設定 }\end{array}$ & $\begin{array}{l}\text { 締固め性が高く高品質な低透水層を構 } \\
\text { 築できる材料の選定と, 要求機能を満 } \\
\text { たす目標値の設定について, 既往研究 } \\
\text { を調査して設定する. }\end{array}$ \\
\hline (2) & $\begin{array}{l}\text { 材料の含水 } \\
\text { 比の調整 }\end{array}$ & $\begin{array}{l}\text { 選定した材料を対象に，実機を用いた } \\
\text { 練混ぜ試験を目標值を設定して実施 } \\
\text { し，その範囲内で調整できるのかを確 } \\
\text { 認する. }\end{array}$ \\
\hline (3) & $\begin{array}{l}\text { 材料の撒出 } \\
\text { し・敷均し }\end{array}$ & $\begin{array}{l}\text { 選定した材料を対象に，実機を用いた } \\
\text { 撒出し・敷均しを実施し，均一に撒出 } \\
\text { し・敷均しできるのかをかさ密度を測 } \\
\text { 定することによって確認する. }\end{array}$ \\
\hline (4) & $\begin{array}{l}\text { 転圧による } \\
\text { 締固め }\end{array}$ & $\begin{array}{l}\text { 転圧パターンを変化させて施工し，デ } \\
\text { 一タを採取する. }\end{array}$ \\
\hline (5) & $\begin{array}{l}\text { 施工後の品 } \\
\text { 質確認 }\end{array}$ & $\begin{array}{l}\text { 実際に施工した低透水層より採取した } \\
\text { 供試体を用いて室内試験を実施する。 }\end{array}$ \\
\hline
\end{tabular}

になることを指向し，拡散場を形成できる条件としてあ る部材厚さのときの透水係数を $1.0 \times 10^{-11} \mathrm{~m} / \mathrm{s}$ 以下と設定 している5 . 施工時のばらつきや長期的な変質等の影響 を考慮してこれよりも高品質な低透水層を構築すること が望ましい.

また，もう一つの技術要件は不飽和時の強度であるが， これに関しては「7. 施工後の品質管理」で詳述するよう に, 既往の検討)で底部低透水層に上載荷重が加わった 時の検討を解析的に実施しており，力学的に安定である と評価された強度定数 (粘着力 $c$, 内部摩擦角 $\phi$, 弾性係 数等）が示されている. その程度の強度定数が確保でき れば，十分な性能を有すると判断できる.

ここでは，そのような高品質な低透水層を構築するた めの材料の選定と施工時における各特性の目標值の設定 について述べる.

\section{(1) 材料の選定}

低透水層としてのベントナイトについて，既往知見を もとにベントナイトが持つ特性および施工性を調査し, 検討を行った．高レベル放射性廃棄物地層処分やTRU廃 棄物処分分野でのベントナイト材料として研究されてい る粉末状ベントナイト（クニミネ工業製（山形県，月布 産））は，高い乾燥密度に締め固めるためには大きな締 固めエネルギーが必要である゙。一方, 粉末状にする前 の粒状ベントナイト（同じく，クニミネ工業製（山形県 月布産），以下，粒状ベントナイトとする）は，粉末状 ベントナイトよりも低い締固めエネルギーで高い密度を 達成することができる見込みが示されている8)。これら の知見および現場での施工性等の観点から, 本論文の低 透水層として, 粒状ベントナイトを採用した. 表-3に粒 状ベントナイトの材料特性值”を，図-2に本論文に用い 
表-3 使用材料・粒状ベントナイトの材料特性 ${ }^{9)}$

\begin{tabular}{|c|c|c|}
\hline 項目 & 平均値 & 範囲 (3o ) \\
\hline 最小密度（Mg/m $\left.{ }^{3}\right)$ & 1.191 & $1.185 \sim 1.197$ \\
\hline 最大密度 $\left(\mathrm{Mg} / \mathrm{m}^{3}\right)$ & 1.407 & $1.395 \sim 1.419$ \\
\hline 土粒子密度 $\left(\mathrm{Mg} / \mathrm{m}^{3}\right)$ & 2.650 & $2.599 \sim 2.701$ \\
\hline 含水比 (\%) & 7.06 & $6.67 \sim 7.45$ \\
\hline 液性限界（\%) & 346.9 & $330 \sim 360$ \\
\hline 塑性限界（\%) & 22.7 & $20.3 \sim 25.1$ \\
\hline $\mathrm{pH}$ & 10.0 & $9.9 \sim 10.1$ \\
\hline $\begin{array}{l}\text { メチレンブルー吸着 量 } \\
(\mathrm{mmol} / 100 \mathrm{~g})\end{array}$ & 72.2 & $58.0 \sim 86.3$ \\
\hline $\begin{array}{l}\text { モンモリロナイト含有量 } \\
(\%)\end{array}$ & 51.5 & $41.4 \sim 61.6$ \\
\hline 膨潤力（ml/2g） & 14.2 & $10.5 \sim 17.8$ \\
\hline 鉱物組成 & \multicolumn{2}{|c|}{$\begin{array}{l}\text { モンモリロナイト, 石英, ゼオ } \\
\text { ライト, 長石, 方解石, 黄鉄鉱 }\end{array}$} \\
\hline $\begin{array}{l}\text { 陽 イ オン 交 換 容 量 } \\
\text { (meq/100g) }\end{array}$ & 65.6 & $55.2 \sim 75.9$ \\
\hline
\end{tabular}

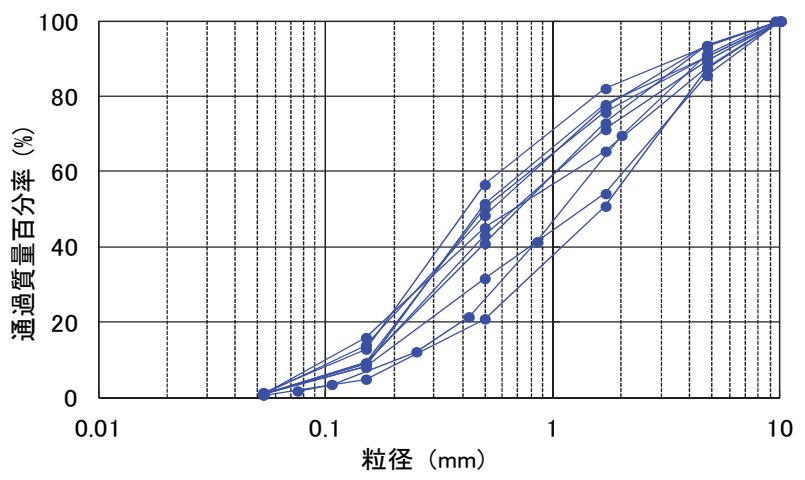

図-2＼cjkstart粒状ベントナイトのふるい分け試験の結果

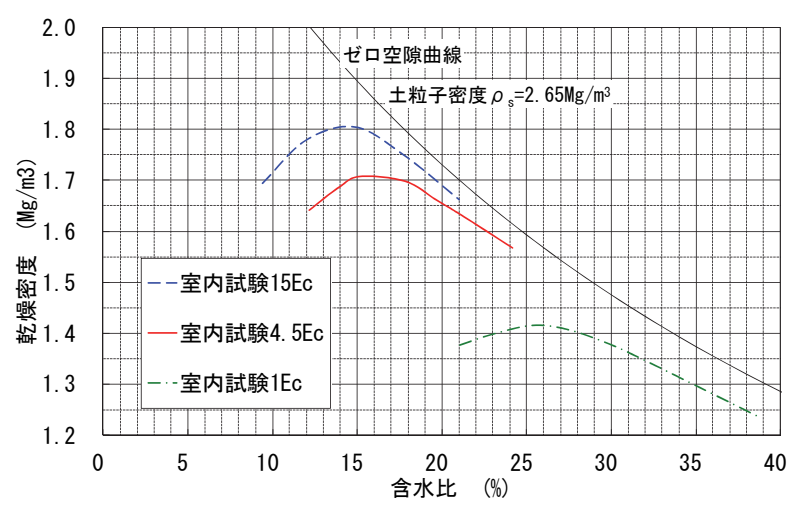

図-3＼cjkstart粒状ベントナイトの締固め試験結果

た粒状ベントナイトのふるい分け試験の結果を示す．表 -3のデータは, 母数が10〜80点であり,「範囲」とは,

$\lceil$ 平均值 $\pm 3 \sigma 」$ の範囲である。 また，最小密度・最大 密度は，「JIS A 1224 砂の最小密度・最大密度試験方 法」を適用して測定した結果としている99.

図-3に，締固めエネルギー15Ec，4.5Ec，1Ecで行った 粒状ベントナイトの締固め試験結果を示寸.

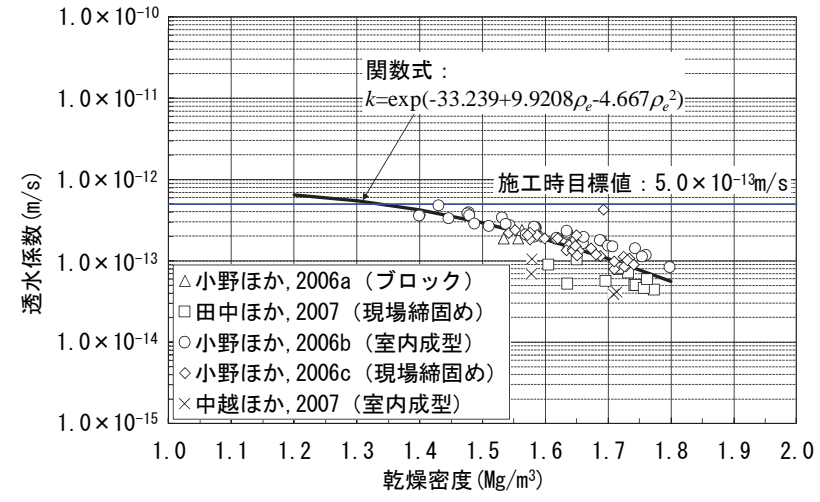

図-4 粒状ベントナイトの透水係数と乾燥密度との関係 ${ }^{10) ~ 14) ~}$

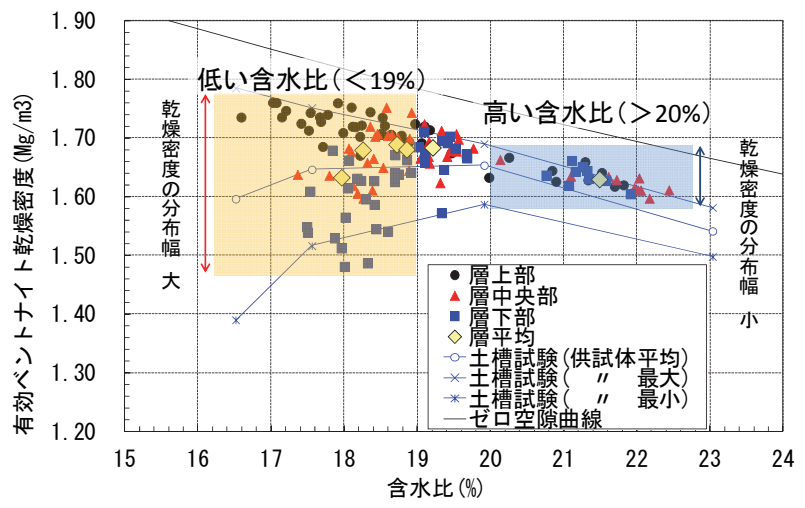

図-5 施工層を上下方向に 3 分割して測定したコア単位の 有効ベントナイト乾燥密度の分布 ${ }^{15}$

\section{（2）要求される低透水性を満たす透水係数の設定}

低透水層の技術要件の一つは，先述のとおり透水特性 であり，低透水性が求められるが，本論文での目標值は， 施工時のばらつきや長期的な変質等の影響を考慮し既往 研究 $)^{5}$ の透水係数の值 $\left(1 \times 10^{-11} \mathrm{~m} / \mathrm{s}\right.$ 程度 $)$ よりも1 2 桁程 度低い $1 \times 10^{-12} \mathrm{~m} / \mathrm{s} \sim 1 \times 10^{-13} \mathrm{~m} / \mathrm{s}$ と，その中間の值であ る5 $\times 10^{-13} \mathrm{~m} / \mathrm{s}$ を暫定的に目標值として設定した．低透水 層の目標厚さは, 既往研究5を参考にして1mとしたが, この值に対して下限值，上限值を定めず，施工精度を確 認することとした.

\section{（3）透水係数に代わる施工時の目標値の設定}

低透水層の透水係数を，そのまま施工管理上の目標値 （以下，管理目標值）として，日常的に測定することは， 測定時間が長期間（数十日程度）となるため, 現実的で はない．現場での施工時においては，日常の施工管理が しやすいよう透水係数に替わる管理目標值を定めて管理 することとした．本論文で選定した粒状ベントナイトと 産地・材質が同じ粒状ベントナイトの透水係数を測定し た既往研究10)14)の結果より得られる透水係数と乾燥密度 との関係は，図-4のような相関性を示す。一般的な土質 材料では，透水係数は含水比にも影響を受けるが，図-3 で示したデータの含水比は15〜28\%程度の間に分布し， 
乾燥密度の違いによる影響よりも含水比の違いによる影 響は小さいと思われる，そのため，本論文では，透水係 数に与える影響が大きいのは乾燥密度であると考え，こ の乾燥密度と透水係数の相関関係より, 乾燥密度を管理 目標値として採用し, 乾燥密度のばらつきを少なくする ことを目指した. 先述のように，低透水層の透水係数の 目標值 $5 \times 10^{-13} \mathrm{~m} / \mathrm{s}$ に対応する乾燥密度は図-3によれば約 $1.4 \mathrm{Mg} / \mathrm{m}^{3}$ となるが，本論文では，施工時に生じるばらつ きに対してある程度の余裕を持たせ若干大きめの乾燥密 度とし, 乾燥密度が高すぎても, ベントナイトが吸水し た時に発生する膨閏圧が大きくなりすぎることを避ける ために上限值を設け，管理目標值を乾燥密度 : $1.6 \pm 0.1$

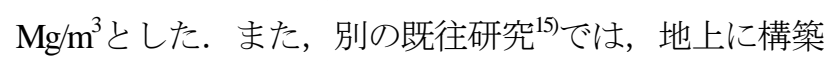
した試験用ピット（幅 $1 \mathrm{~m} \times$ 長さ $17 \mathrm{~m})$ の中で1層当りの 仕上り厚さ0.1mで行った締固め工法の施工要素試験の結 果，同一の層内で密度分布が発生し，材料の含水比が高 くなれば分布幅が小さくなることが，図-5に示した有効 ベントナイト乾燥密度と含水比の関係のように報告され ている. 含水比 $21 \%$ 程度とすれば乾燥密度のばらつきを 小さくすることが期待できるので，含水比の調整に係る 管理目標值を，調整時に生じるばらつきを考慮して，含 水比 : $21 \% \pm 2 \%$ とした.

\section{（4）不飽和時の強度に関する目標値の考え方}

不飽和時の強度を満足するための目標值の目安として, 既往の検討 ) で用いた強度定数 (粘着力 $c$, 内部摩擦角 $\phi$, 弾性係数等）が適用可能であると考えられる. このよう な強度定数は, やはり締め固めた後の乾燥密度に影響さ れる. 既往の検討ので用いた強度定数は，本論文と同じ 粒状ベントナイトの乾燥密度 : $1.619 \mathrm{Mg} / \mathrm{m}^{3}$ の時の值であ り，もう一つの技術要件である低透水性を満たすために 暫定的に設定した施工時の管理目標值である乾燥密度 : $1.6 \pm 0.1 \mathrm{Mg} / \mathrm{m}^{3}$ とも似た值である.

したがって，管理目標值である乾燥密度 : $1.6 \pm 0.1$ $\mathrm{Mg} / \mathrm{m}^{3}$ を満足することによって, 自ずと不飽和時の強度 を満足すると考えられるので，本論文では，施工後に試 料を採取し, 想定通りの強度定数が得られるかの確認を 行うこととした．試験結果については，「7. 施工後の品 質管理」で詳述する。

\section{4. 材料の含水比の調整}

\section{（1）含水比の調整方法}

含水比の調整作業フローを図-6 に示寸．材料の含水 比の調整は, 締固め性や一定の品質を確保するために重

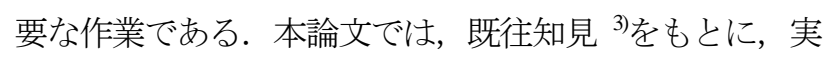
績のあるミキサ（パン型強制混合造粒ミキサ）を用いた。

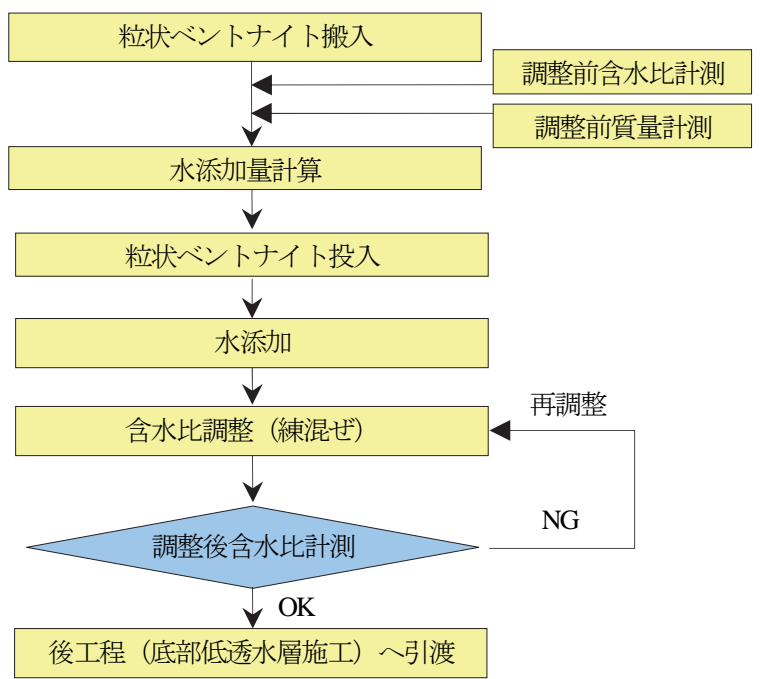

図-6 ベントナイト含水比調整作業フロー（1バッチ毎）

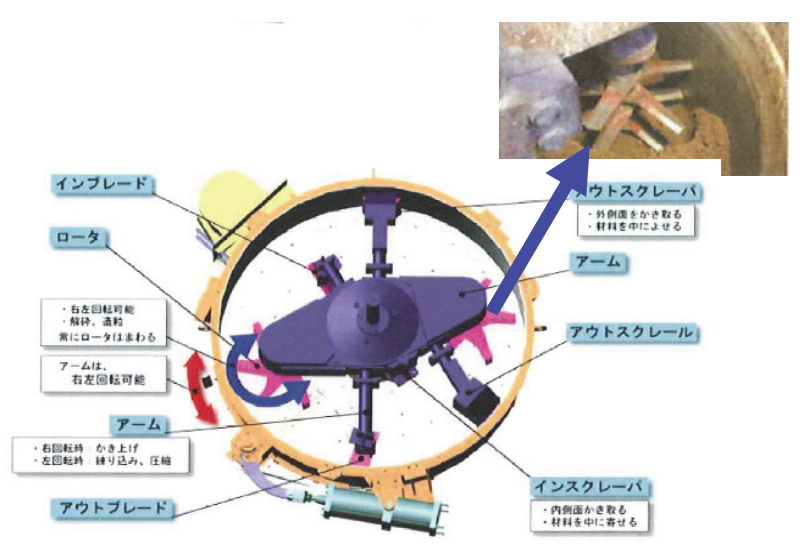

図-7＼cjkstart使用したミキサの内部構造

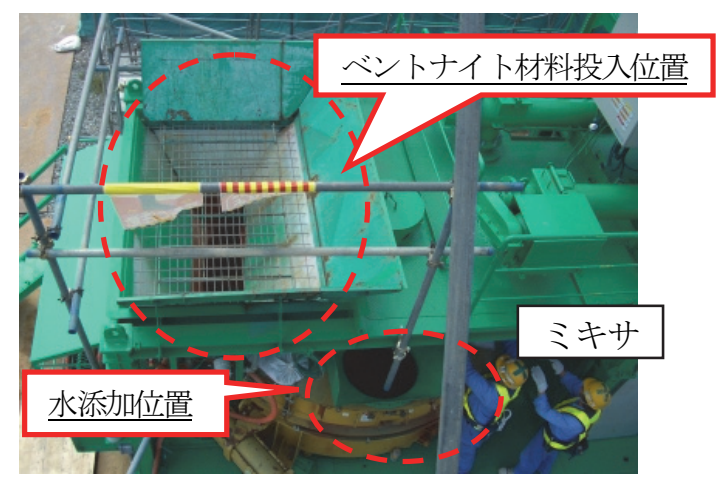

写真-1 含水比調整状況

使用したミキサの内部構造を写真-1および表-4に, 含 水比調整における各設定条件を表-5に示寸. 自然含水比 状態の粒状ベントナイトをミキサに投入し，水道水と混 練することにより，所定の含水比に調整した. 各作業手 順における内容の詳細は次のとおりである.

1) 調整前の初期含水比の測定を行う。測定頻度は粒状心゙ ントナイト約 1 トン毎に 3 点とし, その平均值を初 期含水比とした. 試料の採取量は 1 点あたり $150 \mathrm{~g}$ 程 度とした。 
2) 粒状ベントナイト約 $500 \mathrm{~kg}$ を 1 バッチとして含水比の 調整を行うこととした． 粒状ベントナイトの初期含 水比および質量から水添加量を算出した.

3) 粒状ベントナイトおよび1バッチ毎に算出した所定量 の水を写真-1 に示寸ようにミキ开上部より投入した.

4) ミキサ内のアームおよびローターを高速で 60 秒正転 させて粒状ベントナイトと水を混練し，含水比の調 整を行う。

5)含水比の調整後の粒状ベントナイトをフレキシブルコ ンテナに梱包する．各フレキシブルコンテナに番号 をつけて識別を行ったのち，含水比を測定する．約 $150 \mathrm{~g}$ のサンプル 3 点の平均值をバッチ毎の調整後含 水比とした.

6)フレキシブルコンテナを保管庫に運搬し，平積みで仮 置きする.

調整後の含水比が管理目標值をはずれたバッチについ ては，以下に示す方法で再調整した．なお，再調整する 材料は含水比のばらつきが大きいことが懸念されたため, 含水比の測定は 1 バッチあたり 6 点の頻度で実施した.

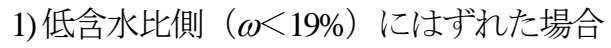

21\%まで含水比を上げるのに必要な水の添加量を算出 し，ミキサ内に低含水比側の材料を投入したのち，所定 量の水を添加し再度ミキサで練混ぜを実施した。

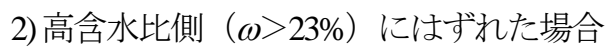

21\%まで含水比を下げるのに必要な水添加前の粒状心゙ ントナイトの量を算出し，高含水比側に調整された粒状 ベントナイトとまとめてミキサ内に投入し，再度混練し た.

\section{（2）含水比の調整結果}

含水比調整後の粒状ベントナイトの含水比の分布を図

表-4 使用したミキサの概要

\begin{tabular}{|c|c|}
\hline 仕様 & 備考 \\
\hline \hline $\begin{array}{c}\text { パン型強制混合造粒ミキサ } \\
\text { (容量 : } 1000 \text { リットル) }\end{array}$ & かくはん翼付回転容器型 \\
\hline
\end{tabular}

表-5 含水比調整における各設定条件

\begin{tabular}{|c|c|}
\hline 項目 & 内容 \\
\hline 使用材料 & 粒状ベントナイト（最大粒径 : 10mm) \\
\hline 材料荷姿 & $\begin{array}{l}\text { 【調整前材料受入れ時】 } \\
\text { フレキシブルコンテナ } \\
\text { (容量 : } 1 \mathrm{t} \text { バッチ) } \\
\text { 【調整後材料払出し時】 } \\
\text { フレキシブルコンテナ } \\
\text { (容量 : } 0.5 \mathrm{t} / \text { バッチ) }\end{array}$ \\
\hline 管理目標値 & 含水比 $21 \% \pm 2 \%$ \\
\hline 材料保管方法 & 仮設保管庫屋内 \\
\hline $\begin{array}{c}\text { 含水比 } \\
\text { 計測頻度 }\end{array}$ & $\begin{array}{l}\text { 1バッチ（0.5t）製造毎に3回 } \\
\text { (約 } 150 \mathrm{~g} \times 3 \text { 試料) }\end{array}$ \\
\hline
\end{tabular}

-8 に示す．管理目標值を外れる割合は全 723 バッチのう ち 14.9\%（高含水比側 : 5.1\%（37 バッチ）, 低含水比 側： 9.8\%（71 バッチ））であった．高含水比側では管 理目標值を大きく外れるものがあった。これは，混練時 に内部に付着した粒状ベントナイトの一部が剥がれて混 入したり，この付着した粒状ベントナイトに過剩に吸水 されるなどの状況が不規則に発生するためと考えられる.

低含水比側 $(\omega<19 \%)$ に外れた材料の再調整後の粒 状ベントナイトの含水比分布を図-9 に，高含水比側（ $\omega$ <23\%）に外れた時の再調整後の粒状ベントナイトの含 水比分布を図-10 に示す。この結果より，再調整を行う ことにより，全バッチを管理目標值の範囲に収めること ができた.

以上より，造粒ミキサを用いた粒状ベントナイトの含 水比の調整では，管理目標值を外孔る場合も発生したが, 適切な再調整を実施することにより，管理目標值に収め ることが十分可能であることが確認できた．ただし，次 章 5. (3)で後述するように, 今回の測定頻度では高含水 比のベントナイトの塊の混入は避けられなかった。

\section{5. 材料の撒出し・敷均し}

\section{(1) 撒出し・敷均しおよび転圧の施工試験概要}

図-11に 1層毎の施工試験フローを示寸，同図には，6

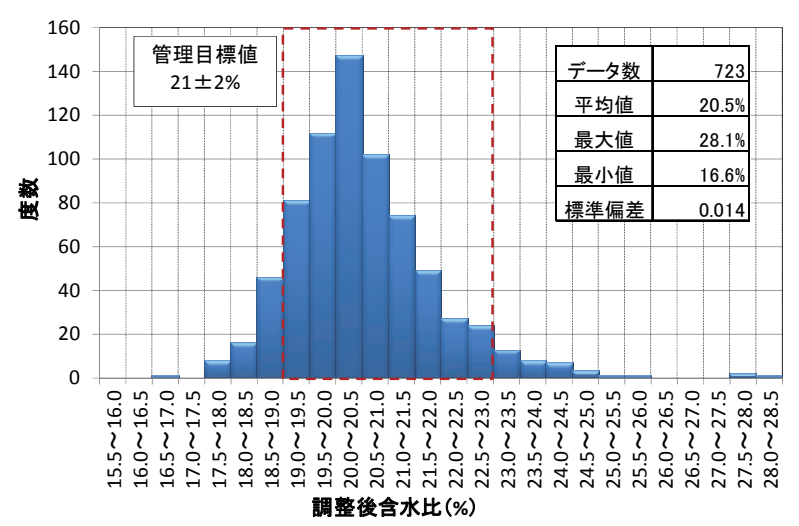

図-8 調整後の含水比分布（全体）

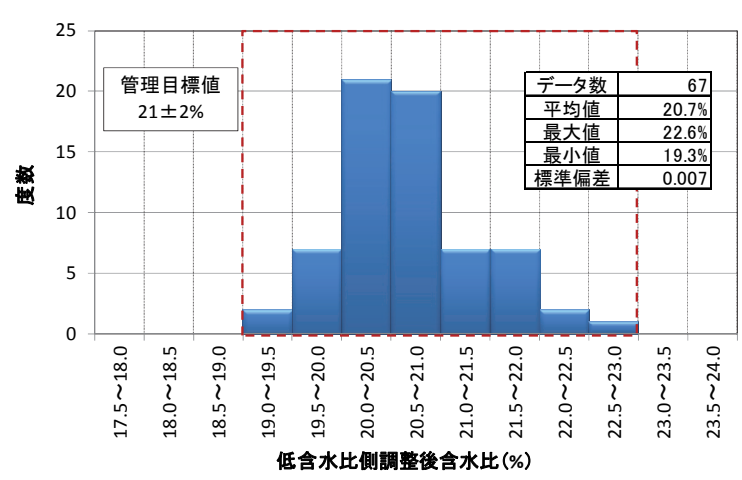

図-9 再調整後の含水比分布（低含水比側（ $\omega<19 \%)$ 


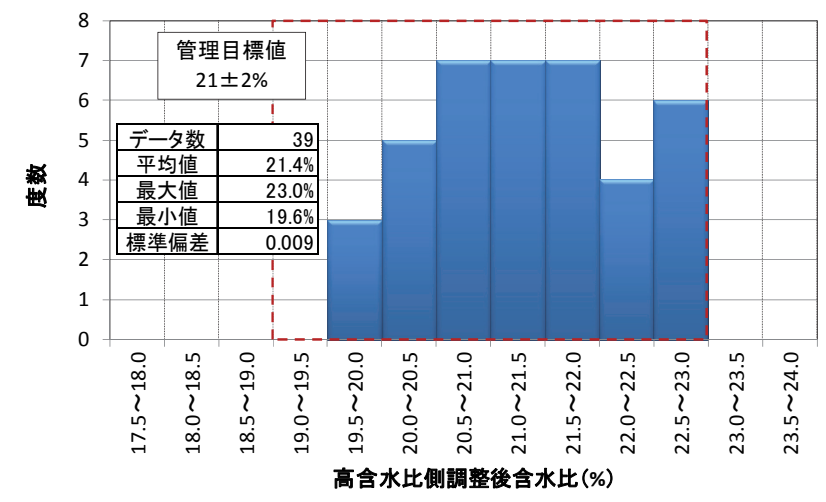

図-10 再調整後の含水比分布（高含水比側（ $\omega>23 \% ）$

章で後述する転圧工程も含めて記載しており，本章では 転圧まで含めた全体概要について説明する.

含水比調整された粒状ベントナイトを使用し，撒出 し・敷均し，予備転圧（2.5t 級舗装用振動ローラ，無振 動）, 初期転圧（大型振動ローラ, 無振動）の各工程を 経た後, 大型振動ローラによる本転圧（振動）を行った. 予備転圧および初期転圧は，適度な水分を含むべント ナイトを高密度に締め固めるには段階的に転圧エネルギ 一を上げる必要があると考え，施工試験を行いながら適 用性を検討し省略可能か確認した。 また，転圧は締固め 残しがないように, $300 \mathrm{~mm}$ 程度オーバーラップさせた.

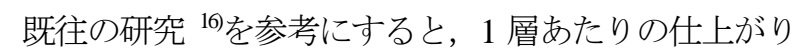
厚さを $10 \mathrm{~cm}$ 程度にすれば, 目標とする乾燥密度に到達 できると考えられたので, 目標とする乾燥密度, 施工面 積および仕上がり厚さより 1 層あたりの材料の投入質量 を算出し，その結果とアスファルトフィニッシャの能力 より撒打し・敷均し厚さ $20 \mathrm{~cm}$ 程度と設定した. 転圧後 の合計厚さが $1 \mathrm{~m}$ となるように施工層数は 10 層で構築 することとした.

\section{（2）撒出し・敷均しの方法}

転圧後の乾燥密度のばらつきを少なくするため, 材料 の撒出し・敷均しを均一に行うことは重要である．実際 の施工時において効率的に撒出し・敷均しをするために は機械による施工が必要である，本論文での実規模試験 における底部低透水層の幅は約 $13.5 \mathrm{~m}$ である. そのため, 大型の施工機械で所定の厚さ・幅を確保しつつ均一な密 度になるような撒出し・敷均しの実施が可能か確認した。 撒出し・敷均しは，写真-2 に示したアスファルト舗 装工事などで用いられている大型フィニッシャを使用し， 図-12 に示したように 3 レーンに分けて実施した. 表-6 に大型フィニッシャの仕様を示す.

大型フィニッシャによる敷均し厚さの管理は, 左右で 高さを自動制御することにより行った.この自動制御の 方法は，既に敷均しを終えたレーンがある側は既設レー ンとの高さ摺付けにより行い，既設レーンのない側（も

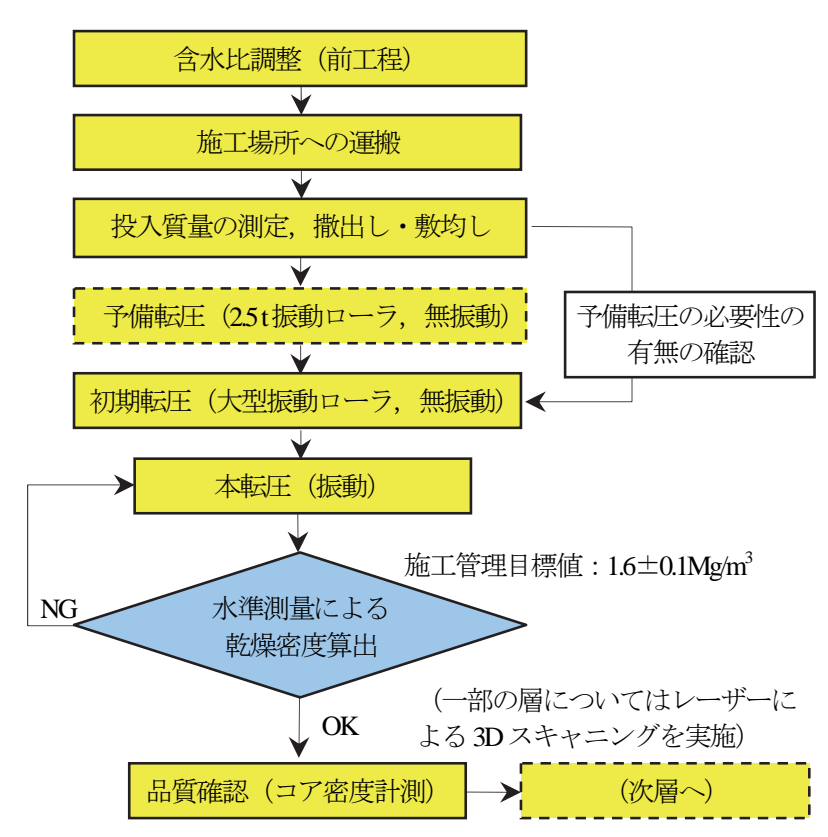

図-11＼cjkstart施工試験の主要なフロー（1層毎）

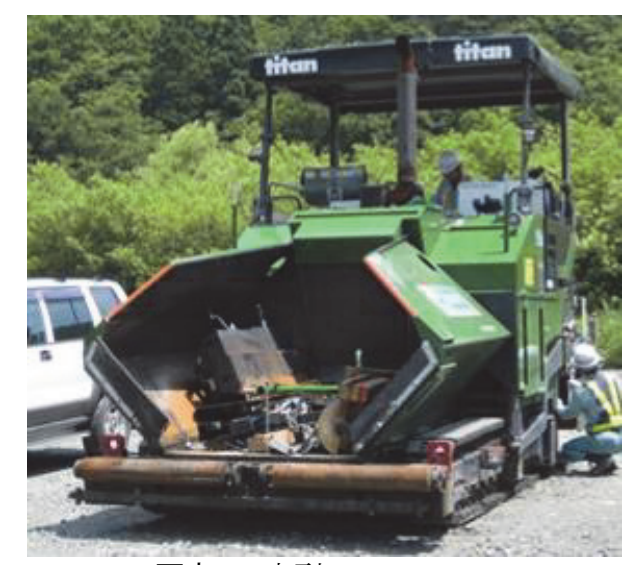

写真-2 大型フィニッシャ

表-6 大型フィニッシャの仕様

\begin{tabular}{|c|c|}
\hline 項目 & 仕様 \\
\hline 総質量 & 19,000kg（5m幅員時） \\
\hline 全長 & $6,247 \mathrm{~mm}$ \\
\hline 全幅 & 3,191mm（ホッパ閉 2,500mm） \\
\hline 全高 & 3,780mm（キャノピートップ迄） \\
\hline 舖装幅 & 2,500mm〜5,000mm（伸縮最大幅） \\
\hline 舖装厚 & 300mm迄 \\
\hline 作業速度 & $0 \sim 20 \mathrm{~m} / \mathrm{min}$ \\
\hline 移動速度 & $0 \sim 20 \mathrm{~km} / \mathrm{h}$ \\
\hline クラウン量 & $-2 \sim+4 \%$ \\
\hline 振動 & 0〜3,600vpm（バイブレータ） \\
\hline 回転数 & 0〜1,700min' (タンパー) \\
\hline
\end{tabular}

しくは壁際）は写真-3 に示すようにレーザーレベルに より高さを制御するものである. 大型フィニッシャでは 撒出し・敷均しができない奥部（切羽壁際より奥行方向 $2 \mathrm{~m}$ 幅）および手前部（手前端部締切より $1 \mathrm{~m}$ ）を人力で 行った.

撒出し・敷均しの順序は, 奥部を行った後, 大型フィ 


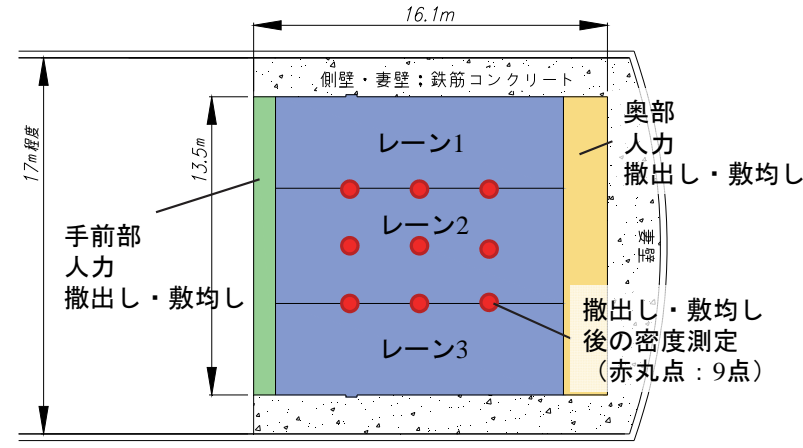

図-12 大型フィニッシャによる撒出し・敷均しのレーン および区分け (平面図)

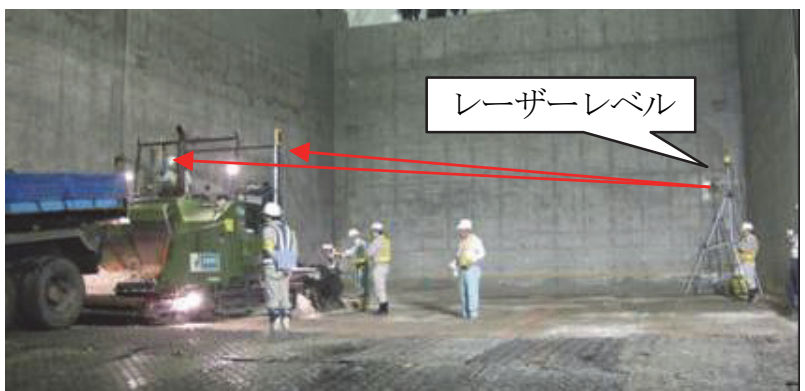

写真-3 レーザーレベルによる敷均し高さ管理

ニッシャで 3 レーンを施工し，最後に手前部を行った (区分けに関しては図-12参照)。

\section{（3）撒出し・敷均しの結果}

大型フィニッシャによる撒出し・敷均し完了時点での 乾燥密度を確認するために, 容積法によるかさ密度測定 を行った. この方法は，各層において内径150mmの鋼製 円筒を測定箇所に挿入し，この円筒内の材料をスプー ン・採取ごて等で全て掬い出して試料を採取し，採取箇 所の撒出し・敷均し厚さの平均值をノギスにより計測し 容積を計算するものである. この容積と採取した試料の 質量よりかさ密度を計算し, さらにかさ密度と含水比よ り乾燥密度を求めた。隣同士の撒出し・敷均しレーンの オーバーラップ等により密度差が生じることが考えられ たので，測定箇所については図-12の赤丸点で示すよう にレーンの中央部およびレーンの端部の合計 9 点で測定 した.

測定結果を図-13に示寸．乾燥密度は0.79 0.95 Mg/ $\mathrm{m}^{3}$ 程度であり，レーンの中央部（0.79〜0.87 Mg/ $\mathrm{m}^{3}$ 程度）に 比べて端部（0.85 $0.95 \mathrm{Mg} / \mathrm{m}^{3}$ 程度）の方が密度が高くな った．これは材料を平坦に敷き均すスクリード（アスフ アルトフィニッシャの後部に構成されている材料を敷均 す部分. スクリード部には，材料を広げるためのスクリ ューフィーダや材料を加熱するための加熱装置, 材料を 突き固めるためのバイブレータやタンパが装備される. 本論文ではバイブレータやタンパを使用していない） の内部において，材料を横断方向に移動させるスクリュ ーフィーダの回転数が高すぎることにより，スクリード

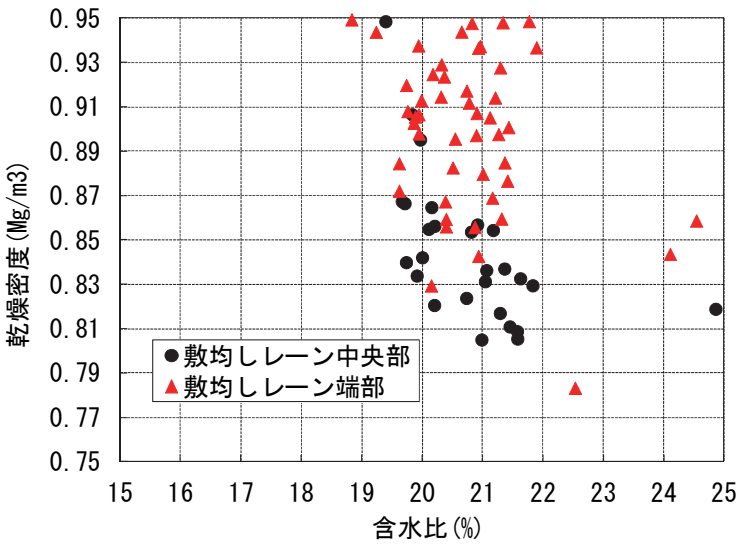

図-13 撒出し・敷均し後の乾燥密度の測定結果

の端部，すなわちレーンの端部の密度が高くなってしま ったものと思われる. また, 混練時に過剩に吸水してで きた高含水比の粒状ベントナイトの塊を, 撒出し・敷均 し作業時に除去することは不可能であったため, 局所的 に含水比が管理目標值の上限值23\%を超える箇所が発生 した．密度のばらつき幅が $0.15 \mathrm{Mg} / \mathrm{m}^{3}$ 程度であったこと， 含水比が管理目標值の上限值23\%を超える箇所ができた ことが転圧後の乾燥密度にどの程度影響があるかは，6 章にて検討する.

\section{6. 転圧による締固め}

粒状ベントナイトを所定の乾燥密度に締め固められる かの確認を行った。 また，転圧機械と転圧回数の関係を 確認するため表-7に示したような組合せで試験を行った。

大型振動ローラは，11t級および19t級を使用し，使用 する機械による仕上り品質の違いを確認した．ケース1 〜ケース4は，19t級大型振動ローラを用いた場合の検討 ケースで，2.5t級振動ローラによる予備転圧の必要性の 有無および大型振動ローラの初期転圧（無振動転圧）, 本転圧（振動転圧）の転圧回数について検討を行ったも のである．ケース5，6については，11級大型振動ロー ラに関する検討ケースである。ケース7については，底 部低透水層の品質保証に資するための試験ケースとし, 同一の転圧方法での施工試験を行い，その際の性能およ び品質のばらつきを検討するためのデータを取得する試 験ケースとした。 また，2，5，10層目を施工した時点で の表面の不陸の程度の確認を行った.

\section{(1) 転圧に用いた施工機械}

図-14に振動ローラの種類による施工箇所の区分けを 示す．中央付近である一般部，転圧機械の乗り込み口で ある手前端部，壁際の大型振動ローラが施工できない奥 部および側部に区分けした. 
表-7 試験ケース

\begin{tabular}{|c|c|c|c|c|c|c|c|c|}
\hline \multicolumn{2}{|c|}{ ケース No. } & 1 & 2 & 3 & 4 & 5 & 6 & 7 \\
\hline \multicolumn{2}{|c|}{ 施工層 } & 1 & 2 & 3 & 4 & 5 & 6 & $7 \sim 10$ \\
\hline \multicolumn{2}{|c|}{ 転圧種類 } & \multicolumn{7}{|c|}{ (転圧回数の目安) } \\
\hline 予備転圧 & 2.5t級 & 2 & 2 & - & - & - & - & - \\
\hline \multirow{2}{*}{$\begin{array}{c}\text { 初期転圧 } \\
\text { (無振動) }\end{array}$} & $19 t$ 級 & 8 & 4 & 4 & 4 & - & - & - \\
\hline & 11t級 & - & - & - & - & 4 & 4 & 4 \\
\hline \multirow{2}{*}{$\begin{array}{l}\text { 本転圧 } \\
\text { (振動) }\end{array}$} & $19 t$ 級 & 6 & 4 & 4 & 2 & - & - & - \\
\hline & $11 \mathrm{t}$ 級 & - & - & - & - & 6 & 4 & 4 \\
\hline
\end{tabular}

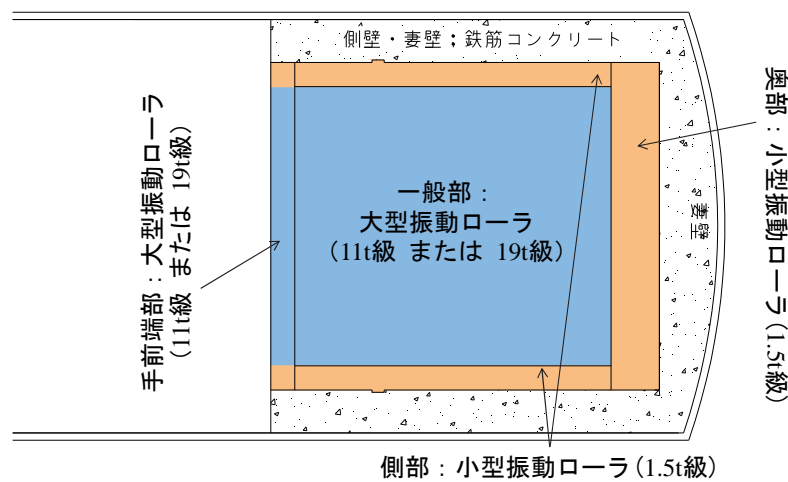

図-14 振動ローラの種類による施工箇所の区分け

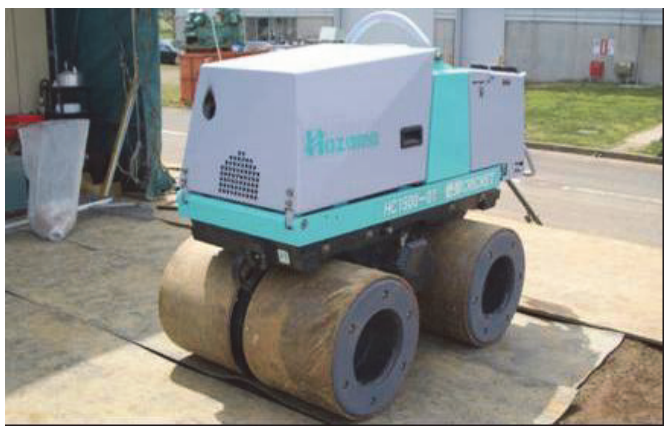

写真-4 小型振動ローラ（1.5t 級 $)$

予備転圧は，アスファルト舗装時の締固めに使用され る2.5t級舗装用振動ローラで行った。奥部・側部の初期 転圧・本転圧には1.5t級の小型振動ローラを使用した

（写真-4）。この小型振動ローラは，本来トレンチ状の 掘削箇所における埋戻し時の転圧等に使用される機械で あり，その構造上，壁際までの締固めが可能である．本 論文では，薄層の締固めに適用させるように振動の方 向・振幅を調整した。表-8に使用した小型振動ローラ

（1.5t級および2.5t級）の主要諸元を示す。一般部および 手前端部の初期転圧・本転圧は，大型振動ローラを使用 して行った.

表-9に，各大型振動ローラの主要諸元を示す．写真-5 に施工試験状況を示す.

\section{（2）転圧後の乾燥密度および出来形の確認方法}

各層の乾燥密度の測定方法および出来形の測定方法を 以下に示す.
表-8 使用振動ローラ（1.5t 級および2.5t 級）の主要諸元

\begin{tabular}{|l|l|l|}
\hline ローラ種別 & \multicolumn{1}{|c|}{$1.5 \mathrm{t}$ 級 } & \multicolumn{1}{|c|}{$2.5 \mathrm{t}$ 級 } \\
\hline \hline 機体長 & $1,500 \mathrm{~mm}$ & $2,675 \mathrm{~mm}$ \\
\hline 機体高 & $1,200 \mathrm{~mm}$ & $1,575 \mathrm{~mm}$ \\
\hline 機体幅 & $610 \mathrm{~mm} \sim 850 \mathrm{~mm}$ & $1,290 \mathrm{~mm}$ \\
\hline 機体質量 & $1,548 \mathrm{~kg}$ & $2,640 \mathrm{~kg}$ \\
\hline エンジン & 空冷2気筒ディーゼル & 空冷 2 気筒ディーゼル \\
\hline 速度 & $1.2 \mathrm{~km} / \mathrm{h}$ & $2 \mathrm{~km} / \mathrm{h}$ \\
\hline 車輪幅 & $278 \times 2 〜 398 \times 2$ & $1,200 \mathrm{~mm}$ \\
\hline 操作 & リモートコントロール & 搭乗式 \\
\hline
\end{tabular}

表-9 大型振動ローラ（11t級, 19t級）の主要諸元

\begin{tabular}{|l|c|c|}
\hline 口ーラ種別 & 11 t級 & $19 \mathrm{t}$ 級 \\
\hline \hline 機体長 & $5,808 \mathrm{~mm}$ & $6,250 \mathrm{~mm}$ \\
\hline 機体高 & $2,972 \mathrm{~mm}$ & $2,910 \mathrm{~mm}$ \\
\hline 機体幅 & $2,250 \mathrm{~mm}$ & $2,530 \mathrm{~mm}$ \\
\hline 機体質量 & $10,950 \mathrm{~kg}$ & $19,400 \mathrm{~kg}$ \\
\hline 周 期 & $30 \mathrm{~Hz}$ & $28 \mathrm{~Hz}$ \\
\hline 振 幅 & $1.8 \mathrm{~mm}$ & $1.8 \mathrm{~mm}$ \\
\hline 起 振 力 & $236 \mathrm{kN}$ & $343 \mathrm{kN}$ \\
\hline 速 度 & $2 \mathrm{~km} / \mathrm{h}$ & $2 \mathrm{~km} /$ \\
\hline 車 輪 幅 & $2,130 \mathrm{~mm}$ & $2,150 \mathrm{~mm}$ \\
\hline 操 作 & 搭乗式 & 搭乗式 \\
\hline
\end{tabular}

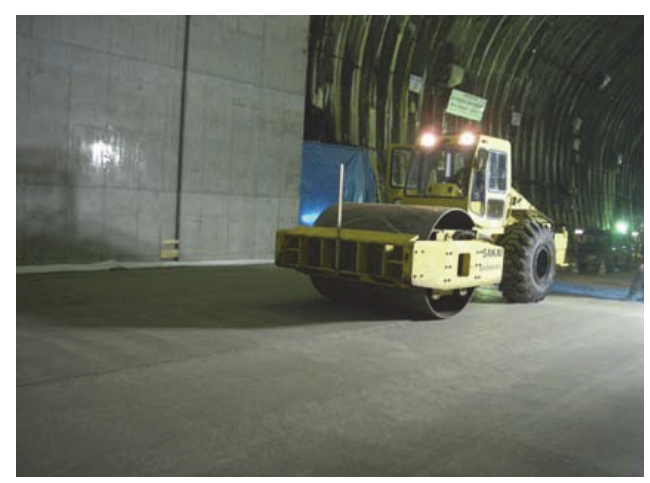

写真-5 大型振動ローラによる底部低透水層の施工試験状況

仕上り面の高さ管理も兼ねて実施するレベルによる水 準測量（以下，レベル測量）の結果と，着手前に測量し た幅員と奥行きの寸法值から，各層の体積を算出した. この体積と材料投入前のフレキシブルコンテナの質量を 電子吊り科（1t，0.5kg 単位）で測定することで管理した， 各層の材料の投入量 (湿潤質量) および平均含水比から その層の全体での「平均的な」乾燥密度を算出した。レ ベル測量は 1 層あたり 195 点測定した. 一部の層（施工 前，1，2，5，10 層目）については，3 次元スキャナを 用いて，仕上り面を計測し，レベル測量との整合性を確 認するとともに，レベル測量と同様にその層全体での

「平均的な」乾燥密度を算出した。 また, 仕上り面のス キャナ情報により，平滑性の確認を実施した。

転圧完了後, その層からコアを採取して乾燥密度を測 定した。コアドリルを用いて直径 $98 \mathrm{~mm}$, 高さ約 $100 \mathrm{~mm}$

（1層あたりの厚さ）の大きさでコアを採取し，1層目： 39点, 2～6層目：各層21点，7～10層目：各層29点, 計 
260点を採取した．採取したコアの質量およびノギスを 用いて測定した寸法より求めた体積から湿潤密度を算出 した（以下，ノギス法）。密度算出後のコアは粉砕し， 炉乾燥法によって含水比を測定し，そのコアの乾燥密度 を求めた. また，一部のコアについては，同一層内での ばらつき（乾燥密度の分布）を評価するため，上下方向 に3分割して測定した.

\section{（3）乾燥密度による仕上がりの評価}

各層のコアの乾燥密度の測定結果の平均值を図-15に 示す. 各層から採取したコアの乾燥密度の平均值はいず れの層でも管理目標值を満足し，19t級大型振動ローラ による施工層の密度は11t級大型振動ローラによる施工 層より大きいという結果になった.

19t級大型振動ローラを用いた1層目〜4層目では2.5t級 小型振動ローラによる予備転圧の有無や大型振動ローラ による無振動転圧である初期転圧の転圧回数の違いによ る有意な差は見られなかった. 3層目と層目で比較する と, 転圧回数と達成密度の間に相関がみられ, 転圧回数 の少ない4層目の方が密度は小さい結果となったが，そ れでも十分に管理目標を満足する結果であった.

1層目〜4層目の結果より，11級大型振動ローラを用 いた5，6層目のケースでは2.5t級小型振動ローラによる 予備転圧は行わないこととし，また無振動転圧による初 期転圧の回数は4回とした．5，6層目では11t級大型振動 ローラによる本転圧（振動転圧）回数を変えて試験を行 ったが，本転圧の回数が4回でも施工管理目標を満足す ることが分かった，そこで，7層目以降では同一の転圧 回数（無振動4回，振動4回）で施工を実施したが，いず れの層においても管理目標值を満足する結果を得た.

なお，5，6層目の仕上り密度は7～10層目の密度より 大きい值となったが，5，6層目の密度が相対的に大きい 原因としては，使用材料の含水比の影響が考えられる.

5，6層目で使用したベントナイトの含水比の平均值は $20.0 \%$ で7層目〜 10層目（20.7\%～20.8\%）より小さく，使 用した材料に差があった．図-16に5層目〜10層目での各 層の含水比と乾燥密度の関係を示寸.この図からも， 5, 6層目で乾燥密度が高くなる傾向となるのは, 相対的に 低かった含水比の影響が考えられる。

7層目〜10層目でのコアの乾燥密度は管理目標值であ る1.50〜 $1.70 \mathrm{Mg} / \mathrm{m}^{3}$ の間に分布し，その中でも $1.55 \sim 1.65$ $\mathrm{Mg} / \mathrm{m}^{3}$ の間での分布割合が大きくなった．同一転圧回数 で施工しても，乾燥密度はこの程度のばらつきが生じる ことを確認できた.

また，含水比が管理目標值の上限值（23\%）を超える 箇所でも乾燥密度は $1.5 \mathrm{Mg} / \mathrm{m}^{3}$ を超えることを確認したた め, 含水比が多少高くても転圧後の乾燥密度に与える影 響は小さいと考えられる.
各層ごとにまとめたコアの乾燥密度のヒストグラムを 図-17に示す，全体的に管理目標值に対して高めの仕上 り密度となったが, 平均值は $1.64 \mathrm{Mg} / \mathrm{m}^{3}$ で管理目標値の 範囲内に入った。ばらつきについては, 標準偏差が $0.039 \mathrm{Mg} / \mathrm{m}^{3}$ ，分布範囲が $0.220 \mathrm{Mg} / \mathrm{m}^{3}$ となった。 下限側は 管理目標值を下回らなかった. 上限側は管理目標值を全 体の $4.6 \%$ 程度の度数が超過し, 最大值は $1.727 \mathrm{Mg} / \mathrm{m}^{3}$ であ った. 管理目標值は各仕上がり層全体に対寸る目標であ り，図-17に示すように，局所的な測定值であるコアの

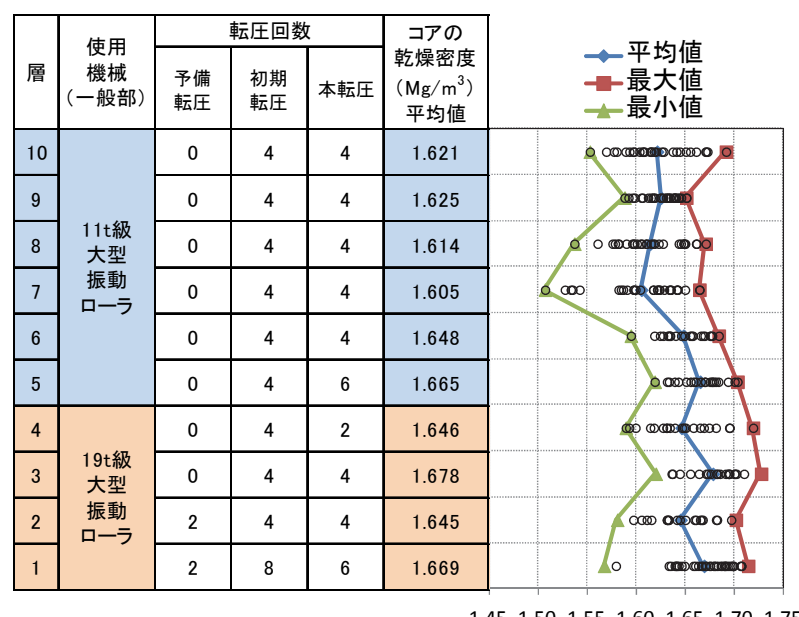

乾燥密度 $\left(\mathrm{Mg} / \mathrm{m}^{3}\right)$

図-15 各層における仕上り乾燥密度と転圧回数の関係

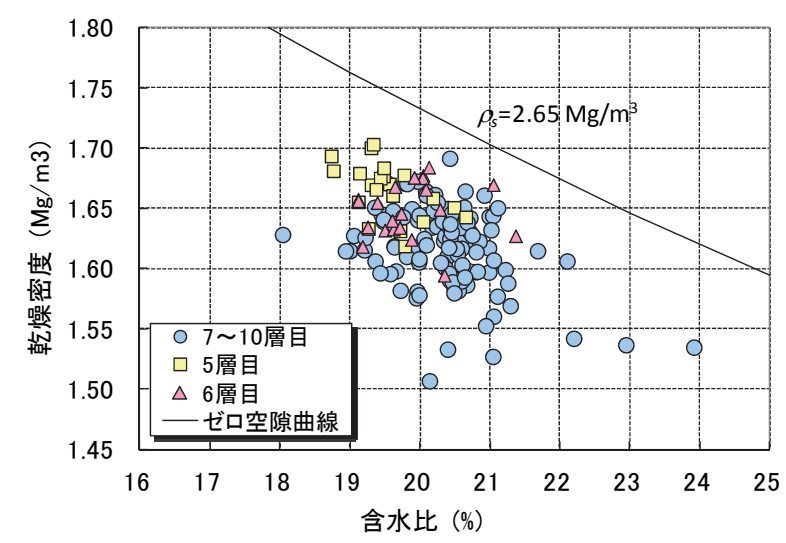

図-16 各層における採取コアの含水比と乾燥密度との関係

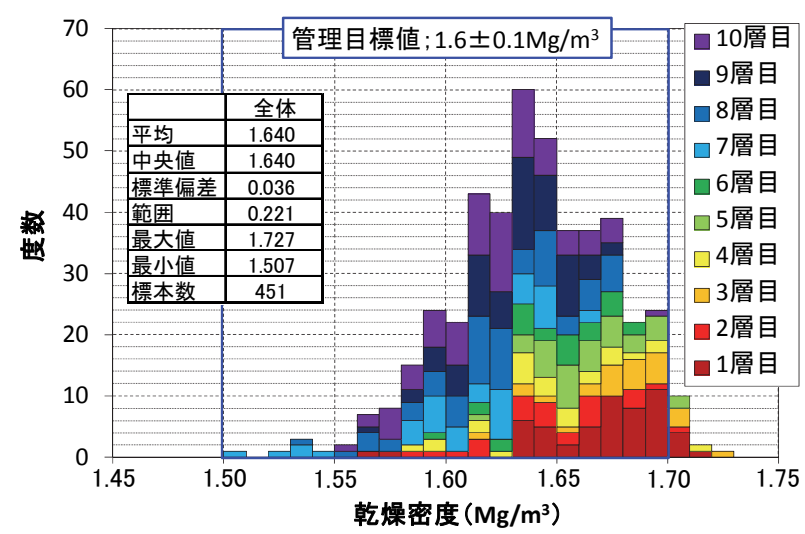

図-17 コアの乾燥密度のヒストグラム 
乾燥密度は一部この管理目標值を外れる值が存在はする ものの，各施工層全体としての平均值は図-15に示した ように満足する結果が得られた.

\section{（4）乾燥密度の分布の評価（層内鉛直方向）}

図-18に厚さ約10cmの各層を上下方向に3分割したコア の乾燥密度の測定結果を示寸．上部は振動ローラに接す る部分，下部は前施工層に接する部分であり，その中間 部分を中部とした.

上部，中部，下部それぞれの平均値は $1.665 \mathrm{Mg} / \mathrm{m}^{3}$, $1.639 \mathrm{Mg} / \mathrm{m}^{3} ， 1.606 \mathrm{Mg} / \mathrm{m}^{3}$ であった. 相対的に上部の乾燥 密度は高めに, 下部の方は低めに分布する結果となり, 同一層内でも乾燥密度の分布が生じる結果となった．上 部の一部（17個）と下部の一部（4個）で管理目標值を 外れる場合があったが，これらは全測定データの $4.1 \%$ であった，全体での密度の分布範囲は $1.437 \sim 1.730 \mathrm{Mg} / \mathrm{m}^{3}$, 平均值は $1.637 \mathrm{Mg} / \mathrm{m}^{3}$ であった. 3分割したコアの乾燥密 度の平均值 $\left(1.637 \mathrm{Mg} / \mathrm{m}^{3}\right)$ は, 分割せずに測定したコア の乾燥密度の平均值 $\left(1.640 \mathrm{Mg} / \mathrm{m}^{3}\right)$ とほぼ整合する結果 となった.

\section{（5）乾燥密度の分布の評価（平面的な転圧条件の違い による影響)}

図-14に示した一般部に加え，壁際の部分および転圧 時にオーバーラップした部分等，平面位置が異なれば転 圧条件も異なると考えられる. 図-19に図-17のデータを 平面的な位置の違いによる転圧条件ごとにまとめたもの を示す.コーナー部とは側壁と妻壁の2面が壁の角部分 であり，壁際とは側壁際部分である. ラップ箇所とは一 般部の転圧時に締固め残しがないように300mm程度オー バーラップさせた部分である. 一般部よりもラップ箇所 の方が相対的に乾燥密度が高くなる傾向が見られるが, その差異は小さいため, 転圧時にオーバーラップさせる ことの影響は少ないと推察される. 壁際やコーナ一部は 転圧しにくい箇所であるが，1.568 1.622Mg/ $\mathrm{m}^{3}$ の範囲で 施工可能であり，管理目標值を満足することを確認した。

\section{（6）撒出し・敷均しの精度が与える影響の評価}

図-13に示したとおり，大型フィニッシャによる撒出 し・敷均しレーンの端部（敷均し端部）とレーンの中央 部（敷均し中央部）では，撒出し・敷均し後の状態での 乾燥密度に0.15 Mg/m³程度の差が生じた。この影響を確 認するため, 敷均し端部と敷均し中央部における転圧後 の乾燥密度を測定した. 図-20に敷均し端部および中央 部の測定結果を示寸.

撒出し・敷均し後の乾燥密度は, 敷均し中央部の方が 敷均し端部より密度は高くなっているが，転圧後の乾燥 密度の差は撒出し・敷均し後の状態での乾燥密度に比心゙

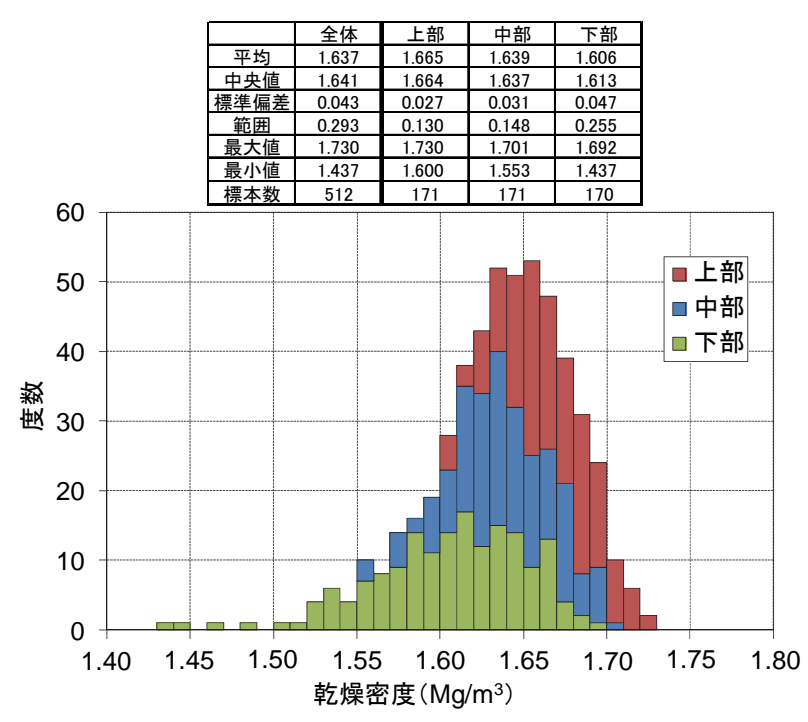

図-18３分割コアの乾燥密度の分布

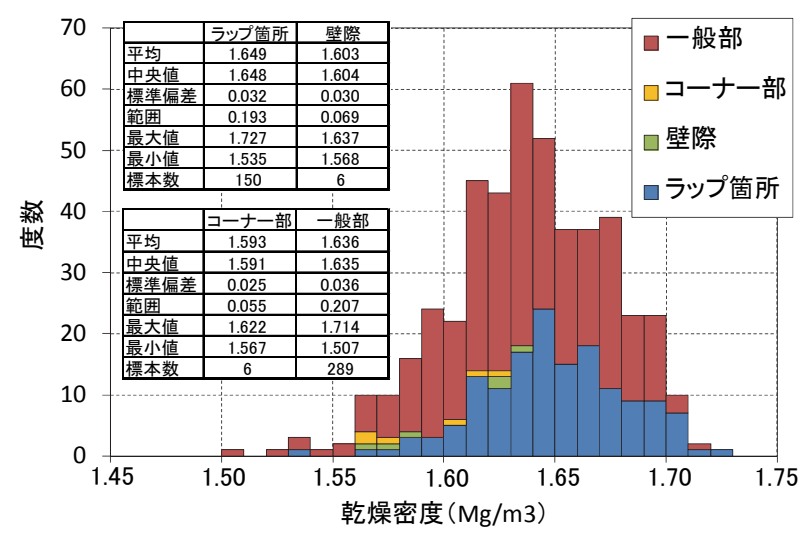

図-19 乾燥密度の平面方向の分布

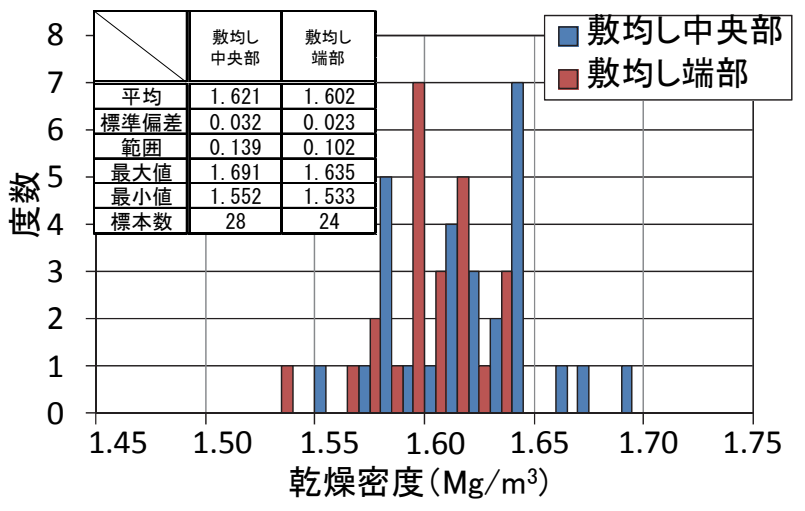

図-20 敷均し端部および中央部の転圧後の乾燥密度の分布

て平均值で $0.02 \mathrm{Mg} / \mathrm{m}^{3}$ 程度に小さくなっていることが確 認された．同一の転圧機械を用いて同じ回数で転圧した 場合，転圧面に与えられる締固めエネルギーがほぼ一定 になると考えられるので, 転圧後に到達寸る乾燥密度は ある一定值に収束すると考えられる. 撒出し・敷均し時 の乾燥密度差は，次節で説明するように，仕上がり表面 の高低差（表面の不陸）に影響した.

換言すれば，今回の撒出し・敷均しの精度であれば， 転圧後の乾燥密度のばらつきに与える影響は小さいと考 
えられる.

\section{（7）転圧後の不陸の評価}

底部低透水層の仕上がり面は，上部構造物の施工基盤 面となるため, 不陸を小さくし，所定の標高になるよう にすることが求められる. 転圧後の仕上がり面の標高と 不陸を確認するため，3次元スキャニングによる測定を 施工試験前，2，5，10層目終了時に行った．表-10に最 終仕上り面の測定值を, 図-21に3次元スキャニングによ る10層目の仕上がり面の等高線図を示す。等高線図の上 側が空洞の奥部にあたる妻壁側であり，左軸の数字（84 ～99）が小さいと坑口側となる. 凡例のコンターの色は, 赤ければ仕上がり高さが相対的に高いことを示している. 中間部分の色で-88.46という数字は，施工目標となる設 計標高值 $(\mathrm{m})$ であることを示す.

奥部の妻壁から約 $1 \mathrm{~m}$ (左軸の数字では97.5付近）のと ころで尾根状に標高が高くなり，手前端部（左軸の数字 では83.5〜85.5）でも面的に標高が高くなった．前者は 一般部と奥部（図-12および図-14参照）との境界部であ

表-10 最終仕上り面の測定值（単位; $\mathrm{m}$ )

\begin{tabular}{|l|l|}
\hline \multicolumn{1}{|c|}{ 項目 } & \multicolumn{1}{c|}{ 測定值 } \\
\hline \hline 設計標高值 & -88.460 \\
\hline 標高の平均值 & -88.4701 \\
\hline 標準偏差 & 0.0160 \\
\hline 最大值 & -88.4181 \\
\hline 最小值 & -88.5005 \\
\hline 設計標高值との差 $(+$ 側 $)$ & 0.0419 \\
\hline 設計標高值との差 $($ 一側 $)$ & 0.0405 \\
\hline 分布幅 (最大值一最小值) & 0.0824 \\
\hline 測定点数 & 21,735 点 \\
\hline
\end{tabular}

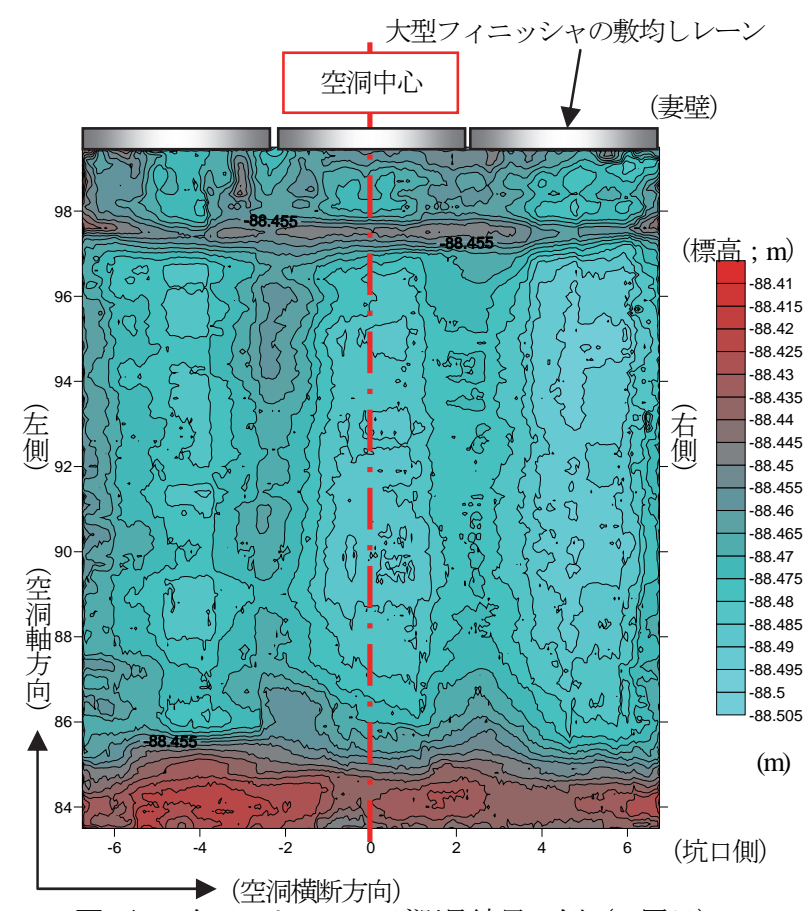

図-21３次元スキャニング測量結果の例（10層目）
り，大型振動ローラがこの境界部付近で振動転圧を停止 することによる影響で不陸が発生したと考えられる.

後者は，10層目においてはこの部分に必要な量より多 い材料を投入したことにより所定の高さを超過したこと が原因と考えられる，2，5層目終了時点での3次元スキ ヤニングの結果より，適切な量を投入すれば手前端部で 標高が高くならないことを確認している ${ }^{17)}$ ¿このように 空洞軸方向では奥部の一部・手前端部で標高が高くなつ ているが，その他の部分での不陸は小さい.

一方，空洞横断方向での不陸は，空洞中心から左右に 約 $2 \mathrm{~m}$ の付近と側壁部近傍で標高が高くなる傾向となっ た.これは大型フィニッシャによる材料の撒出し・敷均 し時のかさ密度の違いによるものと思われる.

最終仕上り面では，標高值の分布幅（最大值一最小 值）は0.0824mとなっており，最大 $0.08 \mathrm{~m}$ 程度の不陸が生 じた. 全体での最終仕上り面の設計標高值との差は概ね $\pm 0.04 \mathrm{~m}$ に仕上がった.

本論文による施工方法で底部低透水層を構築する場合, この程度の不陸が発生することがわかった。

\section{（8）転圧後の部材厚さの評価}

底部低透水層の部材厚さを，底部低透水層の施工基盤 面となる底版コンクリート仕上がり面と10層目完了時の 底部低透水層の仕上がり面の同じ平面座標位置における 標高の差より求めた．全測定点21,735点の部材厚に関す る統計データを表-11に整理した.

底部低透水層の設計厚と最大值・最小值との差はプラ ス側で $0.0413 \mathrm{~m}$ ，マイナス側で $0.0489 \mathrm{~m}$ である.プラス側 は設計標高值との差（0.0419m，表-10参照）とほぼ同じ であるが，マイナス側は設計標高值との差（0.0405m, 表-10参照）より設計厚との差が大きくなった。 これは 底部低透水層の仕上がり面の不陸に加えて底版コンクリ 一ト仕上がり面の不陸が重なったためである. しかし， この場合でも設計值との差は $\pm 0.05 \mathrm{~m}$ 程度であった。

底部低透水層および底版コンクリートの施工誤差を要 因とする仕上がり面の不陸は免れないため，ある程度の 余裕を持たせて施工基盤面（空洞掘削面）を設定するこ

表-11 部材厚に関する統計データ (単位 ; m)

\begin{tabular}{|l|c|}
\hline \multicolumn{1}{|c|}{ 項目 } & 測定值 \\
\hline \hline 設計厚 & 1.0 \\
\hline 平均値 & 0.9901 \\
\hline 標準偏差 & 0.0170 \\
\hline 最大值 & 1.0413 \\
\hline 最小值 & 0.9511 \\
\hline 設計厚との差 (+側) & 0.0413 \\
\hline 設計厚との差 (一側) & 0.0489 \\
\hline 分布幅 (最大值一最小值) & 0.0902 \\
\hline 測定点数 & 21,735 点 \\
\hline
\end{tabular}


表-12 技術要件と品質確認試験との関係

\begin{tabular}{|c|c|c|}
\hline 技術要件 & \multicolumn{2}{|c|}{ 品質確認試験方法 } \\
\hline \hline \multirow{3}{*}{ 透水特性 } & JIS A 1218を参考 & 透水試験 \\
& JS A 1225 & 乾燥密度測定 \\
& JIS A 1217を参考 & 膨潤圧試験 \\
\hline \multirow{3}{*}{ 力学特性 } & JIS A 1216 & 一軸圧縮試験 \\
& JGS 0521 & 三軸圧縮試験 (UU) \\
& JGS 1521 & 平板載荷試験 \\
\hline
\end{tabular}

とは，底部低透水層の設計厚を確保する上で必要である と考えられる.

\section{7. 施工後の品質確認}

施工試験後の底部低透水層が所定の品質を確保できて いるかの確認を行った。 また，得られた結果と主に試験 室で作製された供試体を用いた既往データとを比較し, 試験室で作製された供試体のデータが実際に処分施設を 施工する時の検討材料になり得るかを検証した.

\section{(1) 品質確認試験の概要}

低透水層の要求機能に対する技術要件と本検討で実施 した品質確認試験との関係を表-12にまとめる.

透水特性に係る項目のうち透水係数は，直接的に透水 特性を示すパラメータであり，乾燥密度は透水係数との 相関性が高いことが示されており，間接的に透水特性を 推定できるパラメータであるといえる．また，膨閏圧は， 再冠水後の長期的な観点において, 空洞内充填材の領域 へのはらみ出しや周辺の亀裂・隙間への入り込みに関係 し，透水特性にも影響を与えるパラメータである.

力学特性に係る項目は，一軸圧縮試験，三軸圧縮試験 （UU条件），平板載荷試験によって得られる強度，強 度定数 (粘着力 $c$, 内部摩擦角 $\phi$ ) , 変形係数である. 力学特性は，建設・操業段階における施設の力学的安定 性の確保ができることを確認する項目なので, これらの 試験は再冠水前の状態を想定し，不飽和の状態で試験を 実施した。

転圧後の底部低透水層から採取した試料を対象とし, 表-12に示す各種品質確認試験を行った（平板戴荷試験 は原位置にて実施）。試料採取は10層目の仕上り面から ボーリング等で行った. 回収したコアを整形（トリミン グ）して供試体を作製し試験に供した.

\section{（2）透水試験の結果}

1つの施工層（厚さ約 $10 \mathrm{~cm}$ ）に対して, その上部部分, 中央部分，下部部分からそれぞれ1個ずつ，合わせて3個 の供試体（直径5～10cm，厚多 1～2cm）を作製した. 試 験は差圧型の定圧透水試験とした．透水試験の結果より，

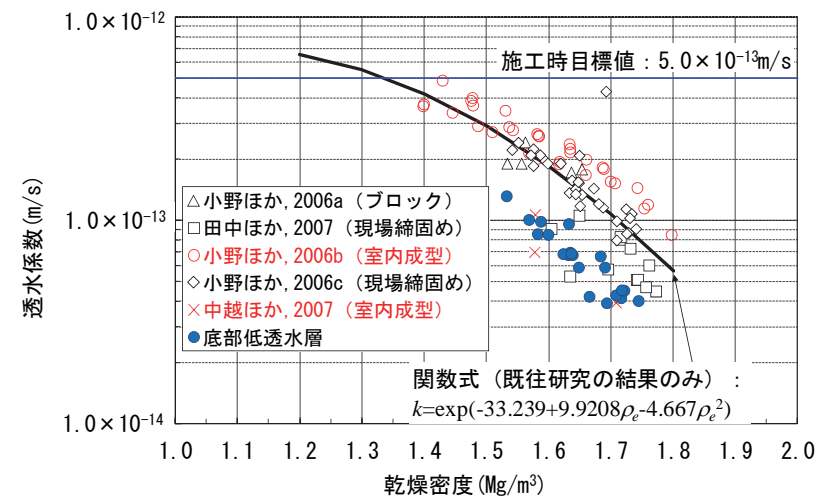

図-22 粒状ベントナイトの透水係数と乾燥密度の関係 ${ }^{10) ~ 14) ~}$

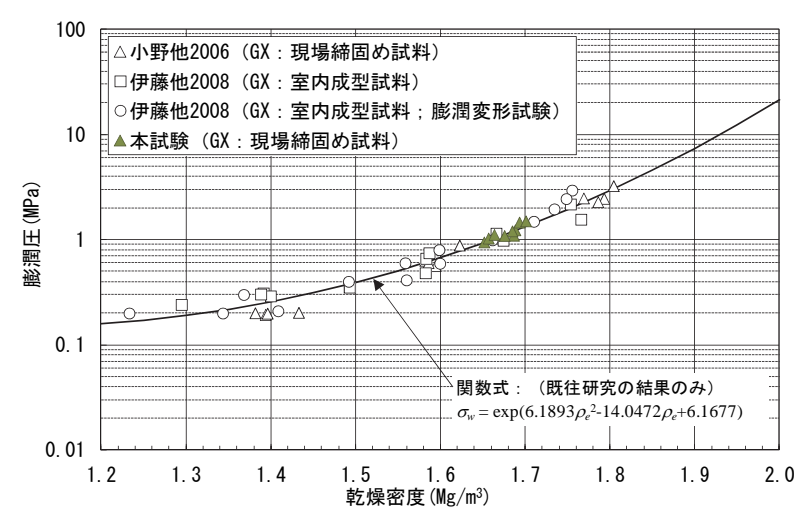

図-23 膨潤圧の測定結果の既存值 ${ }^{18), 19)}$ との比較

透水係数と乾燥密度の相関性を確認した。図-22に試験 結果を示す.

注水開始後約75日後から排水側でも通水が確認され， 約90日で透水係数の值が安定した. 粒状ベントナイトを 対象に取得された既往の知見における透水係数の值 ${ }^{10)}$ 14) と同様に, 乾燥密度と透水係数の相関性が見られる. 図 中の近似式は，これまで得られている透水係数から同定 された近似式で，今回の結果を含まないものである。今 回の試験結果は，近似式に比べると若干小さな值となっ ているが，これまで得られている值とは比較的良く整合 した結果である。

また，底部低透水層から採取した供試体の試験結果と， 既往知見による室内成型供試体を用いた試験結果とが, 同様な乾燥密度と透水係数との相関性をもつことを確認 できたこのことから，室内成型で作成した供試体を用 いた透水試験の結果も，実際の処分施設の設計・建設時 に検討材料として活用できると考えられる.

\section{(3) 膨閏圧試験の結果}

ベントナイト系の材料は，吸水・浸潤すると膨張す る性質を持つ. この膨張により，体積が大きくなる．膨 潤圧とは，ベントナイト系材料が吸水・浸潤した時の膨 張変形（膨潤と表現できる）を拘束し，定体積状態にす るのに必要な圧力のことである. 膨閏圧試験は，供試体 
を定体積状態となるように試験装置にセットし，浸潤さ せることにより発生する荷重を測定するものである ${ }^{18,19}$

施工箇所から採取した試料を用いて室内膨閏圧試験 を実施した。これまでにも粒状ベントナイトを対象にし た膨閏圧試験は実施されており ${ }^{18,}$, 199，その結果と今回の 測定結果の比較を図-23 に示寸．同図の近似式は，これ まで得られている膨閏圧の值から作成された近似式であ り，本論文で得られた結果を含まない．

膨潤圧試験に関しても，底部低透水層から採取した 供試体を用いた試験結果での乾燥密度と膨閏圧との相関 性と, 既往知見で得られている畭燥密度と膨閏圧との相 関性が同様であることを確認できた，すなわち，室内成 型で作成した供試体を用いた膨閏圧測定結果も実際の施 設の設計・建設時における検討材料として活用できると 考えられる.

\section{(4) 力学特性に係る試験の結果}

施工箇所から採取した供試体を用いた一軸土縮試験結 果を図-24，図-25に示す。これまでにも同じ産地・粒径 分布の粒状ベントナイトを対象にした一軸圧縮強さが含 水比と乾燥密度をパラメータとして実施されており20), ベントナイトの一軸圧縮強さは含水比の増加に伴い低下 し, 乾燥密度の増加に伴い増加する傾向となっている. 本論文の試験結果も同様の傾向になった.

図-26に，同じ産地・粒径分布の粒状ベントナイトを 用いた一軸圧縮試験より得られた変形係数 $\left(E_{50}\right)$ と施 工後に実施した平板載荷試験から得られた変形係数と含 水比の関係を示寸。一軸圧縮試験で得られる変形係数

$\left(E_{50}\right)$ は，供試体の一軸圧縮強さの $1 / 2$ の応力と載荷原 点とを結んだ割線静弾性係数として求めた. 平板載荷試 験は, 直径 $300 \mathrm{~mm}$ 載荷板, 1 サイクル方式 (単調載荷) による「地盤の平板載荷試験JGS1521」で行い, 変形係 数は単調載荷ではあるが，接線弾性係数の算定方法を適 用した．2つの測定方法によらず，含水比の増加に伴い， 変形係数が小さくなるような相関性が，同図に合わせて 示した既往知見 ${ }^{20)}$ と同様に見られる.

三軸圧縮試験（UU条件）は，採取時の含水比（不飽 和状態, 3本の供試体の含水比の平均值 : 20.1\%) で, 側 圧を1.0MPa，2.5MPa，4.0MPaで実施し，モールの応力円 から強度定数 $(c, \phi)$ を取得した. 施工箇所から採取 した供試体の強度定数は, 粘着力c : $0.35 \mathrm{MPa}$, 内部摩擦 角 $\phi ; 4.70$ であった.

本論文で得られた変形係数・強度定数が要求機能を満 足する力学特性を確保しているかの確認として, 既往の 研究で実施されている変形解析で用いられている入力パ ラメータとの比較と解析結果をもとに検証した.

この既往研究では, 本論文の底部低透水層と同程度の 性能の材料特性值 (変形係数; 68MPa程度, 乾燥密度;
$1.619 \mathrm{Mg} / \mathrm{m}^{3}$, 粘着力c $: 0.220 \mathrm{MPa}$ ，内部摩擦角 $\phi ; 5.7^{\circ}$ ) をもつ底部緩衝材（本論文における底部低透水層に該 当）を対象にDuncan-Changモデルを適用した変形解析を 行っているの。，その結果によると，底部緩衝材の変形モ 一ドは概ね一次元的であり, 総沈下量の $60 \%$ 程度は廃棄 体の荷重によるものであること, 想定される荷重 （0.41MPa）に対して沈下量は4 $5 \mathrm{~mm}$ 程度であること， Mohr-Coulombの破壊基準で判断した結果, 底部緩衝材に 局所的な破壊は発生しないということが示されており， 本論文で施工した底部低透水層と同程度の性能を有して いれば，廃棄体を含むコンクリートピット等の施設に対 して十分な支持力があると予想される.

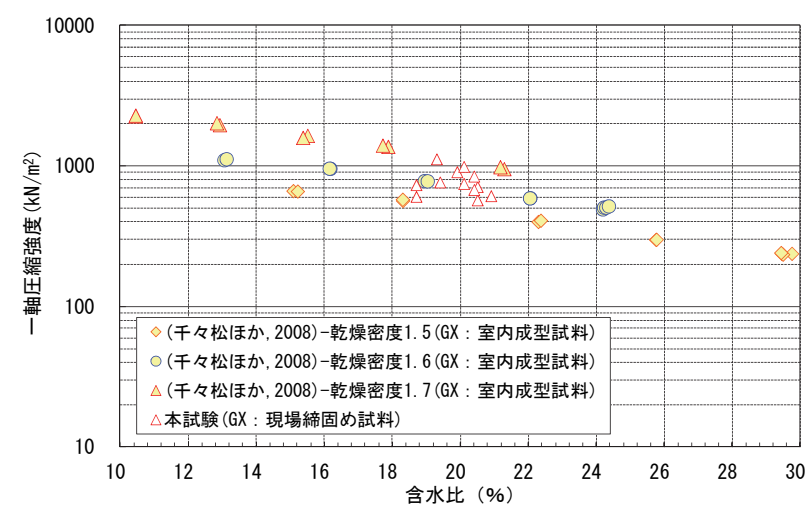

図-24 含水比と一軸圧縮強さの関係

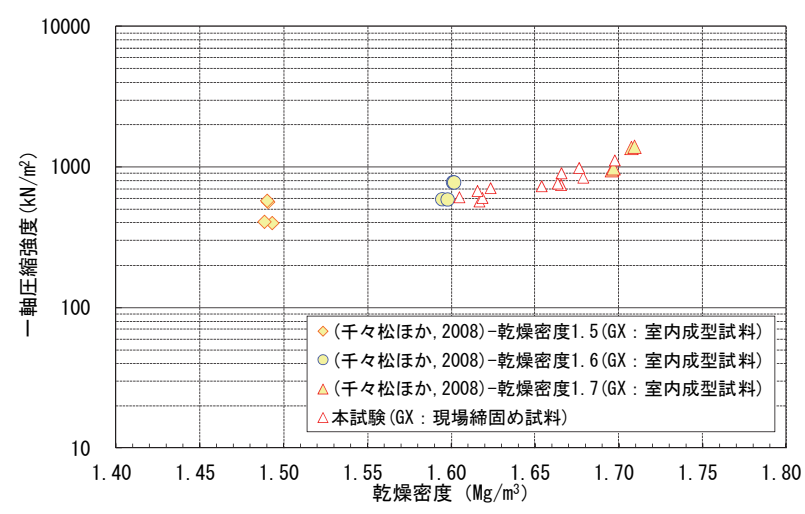

図-25乾燥密度と一軸圧縮強さの関係

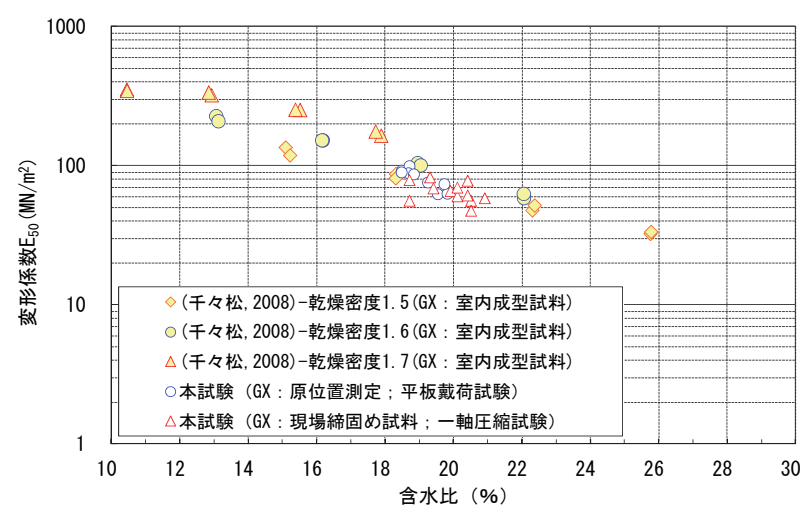

図-26 各試験方法により得られた変形係数の比較 
強度試験に関しても，既往知見で得られている3つの 相関性，すなわち含水比と一軸圧縮強さとの相関性，乾 燥密度と一軸圧縮強さとの相関性，および含水比と変形 係数との相関性が，底部低透水層から採取した供試体を 用いた試験結果からも得られた。 寸なわち, 室内成型で 作製した供試体を用いた強度特性に関する測定結果も実 際の処分施設の設計・建設時に検討材料として活用でき ると考えられる. また，既往研究での変形解析の結果を 参照すると，廃棄体を含むコンクリートピット等の施設 に対して十分な支持力を有していると考えられる試験結 果が得られた。

\section{8. おわりに}

本論文は人工バリアの一つである底部低透水層につい て検討したものである. 本論文で得られた知見は，以下 のとおりである.

1) 高密度な低透水層を構築できる材料として粉末ベン トナイトより締固め性が高い粒状ベントナイトを用 いて，極めて透水係数が小さい低透水層を構築でき ることを確認した。

2) 粒状ベントナイトの含水比調整については, 調整後 の含水比のばらつきの幅は小さかったが，一部に管 理目標值を外れる場合もあった。これらの材料に対 し，適切な再調整を実施することにより，最終的に 管理目標值に収めることが可能であることを確認し た.

3）アスファルト舖装に用いられる大型フィニッシャを 用いても，材料の撒出し・敷均しを実施することが 可能であった．また，そのばらつきの範囲はかさ密 度で $0.15 \mathrm{Mg} / \mathrm{m}^{3}$ 程度であった。

4）小型振動ローラ, 大型振動ローラを組合わせて, 地 下空間でも品質のよい低透水層が構築可能であるこ とを確認した．同一層内の鋁直方向に密度差がある ことを確認したが，乾燥密度は概ね管理目標值に収 まった，平面位置によって異なる転圧条件の影響は， 乾燥密度の分布として認められたが，分布幅が小さ くほとんど影響しないことを確認した．撒出し・敷 均し時の密度の違いが, 転圧後の乾燥密度に与える 影響も小さいことが分かった。 また, 最終仕上がり 面での不陸・層厚のばらつきは $\pm 0.05 \mathrm{~m}$ 程度であった.

5）実際に構築した低透水層から採取した試料を用いた 特性確認試験を実施した。その結果，室内で圧縮成 型された供試体を用いた既往知見の結果は，本研究 で得られたデータと近い結果であることを確認した。 そのため, これまでの室内試験で得られたデータも 実構造物の設計・評価に用いることが可能であるこ
とがわかった。

以上の結果から，本論で取り上げた施工方法の組合わ せ（ミキサ混合による含水比調整，振動ローラによる現 場締固め工法）により, 地下環境においてベントナイト を用いた人工バリア（低透水層）に要求される水準の品 質で構築することが可能であることを確認した.

謝辞 : 本報告は，経済産業省 資源エネルギ一庁からの 委託である平成19年度〜平成20年度「管理型処分技術調 査等委託費（地下空洞型処分施設性能確証試験）」の成 果の一部である.

\section{参考文献}

1) 坪谷隆夫, 寺田賢二, 松村勝秀, 大沼和弘, 窪田 茂: 地下空洞型処分施設性能確証試験一計画概要一, 土木学会第 62 回年次講演会, CS5-073, 2007.

2) (社)土木学会 : 余裕深度処分の地下施設の設計, 品質 管理および検査の考え方， 2009.

3) 伊藤裕紀, 谷智之, 千々松正和, 山本卓也 : ベント ナイトの含水調整に関する検討, 土木学会第 62 回年 次学術講演会講演概要集, CS5-002, pp.163-164, 2007.

4) 小峯秀雄, 緒方信英 : 塑性限界を導入した粘土の締 固め特性の評価法の提案, 土木学会論文集, No.436/III-16, pp.103-110, 1991.9.

5) 電気事業連合会, 核燃料サイクル開発機構：TRU 廃 棄物処分技術検討書一第 2 次 TRU 廃棄物処分研究開 発とりまとめ一, pp.3-11〜3-12, 2005.

6) 財団法人原子力環境整備促進・資金管理センター： 平成 17 年度地層処分技術調査等 TRU 廃棄物関連処 分技術調查地下空洞型処分施設性能確証試験報告書, pp.12-1 12-35, 2006.

7) 核燃料サイクル開発機構：わが国における高レベル 放射性廃棄物地層処分の技術的信頼性一地層処分研 究開発第 2 次とりまとめ一, 分冊 2 地層処分の工学 技術，JNC TN1400 99-022，pp.IV-77～IV-80， 1999.

8) 千々松正和, 吉越一郎, 中越章雄, 雨宮清: ベント ナイトの現場締固め施工に関寸る検討（その 1) 狭险 部の施工確認試験結果, 日本原子力学会 2006 年春の 年会要旨集, B26, p.26, 2006.

9) 伊藤弘志, 千々松正和, 村上利一：ベントナイト層 の現場施工用材料の開発, 第 62 回年次学術講演会概 要集, CS05-001, pp.161-162, 2007.9.

10）小野文彦, 庭瀬一仁, 谷智之, 中越章雄, 千々松正 和：現場締固め工法における締固め層境での透水係 数測定結果, 第 61 回年次学術講演会概要集, CS05059, pp.323-324, 2006.9.

11）田中幸久, 中村邦彦, 工藤康二, 廣永道彦, 仲神元 順, 庭瀬一仁, 小松進一: 地盤統計学手法により不 均一性を考慮した締固めたベントナイト地盤の透水 性評価, 土木学会論文集 C, Vol.63, No.1, pp.207223, 2007.2.

12）小野文彦, 庭瀬一仁, 谷智之, 中島均, 石井卓 : 心 ントナイト原鉱石の高速透水試験ープレス飽和法一, 日本原子力学会「2006 年秋の大会」, p.108, 2006.9.

13）小野文彦, 庭瀬一仁, 谷智之, 中島均, 石井卓 : ベ 
ントナイト原鉱石の高速透水試験一締固め施工した 供試体の乾燥飽和法一，日本原子力学会「2006 年秋 の大会」, p.109, 2006.9.

14）中越章雄, 千々松正和, 庭瀬一仁, 谷智之: ベント ナイトブロックの隙間の密度均一化に関する検討 (その 2) 一透水性に関する検討一，第 62 回年次学 術講演会講演概要集, CS5-008, pp.175-176, 2007.9.

15）工藤康二, 田中幸久, 雨宮清, 中越章雄, 茂呂吉司, 千々松正和, 辻建二, 庭瀬一仁, 小松進一 : ベント ナイト原鉱によるコンクリートピット内締固め試験, 土木学会第 59 回年次学術講演会講演概要集, CS1050, pp.99-100, 2003.

16) 中越章雄, 雨宮清, 茂呂吉司, 千々松正和, 工藤康 二，田中幸久，山崎直，庭瀬一仁，小松進一：ベン トナイト原鉱の締固め特性に関する検討一土槽を用 いた締固め試験結果一, 土木学会第 58 回年次学術講 演会講演概要集, CS07-019, 2003.
17）財団法人原子力環境整備促進・資金管理センター： 平成 20 年度管理型処分技術調査等委託費 地下空洞型 処分施設性能確証試験報告書, pp.3-46〜3-91， 2009.

18）小野文彦, 庭瀬一仁, 谷智之, 中越章雄, 千々松正 和：現場締固め工法における締固め層境での透水係 数測定結果, 土木学会第 61 回年次学術講演会講演概 要集, CS05-059, 2006.

19）伊藤裕紀, 庭瀬一仁, 鈴木康正, 千々松正和：ベン トナイトクニゲル GX の基本特性試験（その 1）膨潤 挙動に関する検討, 第 63 回年次学術講演会講演概要 集, CS05-14， 2008.

20) 千々松正和, 鈴木康正, 伊藤裕紀, 庭瀬一仁 : ベン トナイトクニゲル GXの基本特性試験（その 2）不飽 和支持力に関する検討，土木学会第 63 回年次学術講 演会概要集, CS05-15, 2008.

(2014. 8. 20 受付)

\title{
CONFIRMATION TESTS OF CONSTRUCTION METHOD AND INITIAL PERFORMANCE QUALITY FOR LOW PERMEABLE ENGINEERED BARRIER IN BOTTOM OF RADIOACTIVE WASTE DISPOSAL FACILITIES
}

\author{
Atsuo YAMADA, Masakazu CHIJIMATSU, Tadafumi FUJIWARA, Tsutomu YADA, \\ Yoshihiro AKIYAMA, Hideo KOMINE and Atsushi IIZUKA
}

As for the low permeable layer, important functions are expected as an engineered barrier of radioactive waste disposal for low-level waste with comparatively high radiation levels. On examining the construction methods of this low permeable layer, it is important to confirm the possibility of the construction in the conditions similar to the actual constructed conditions with a true scale size. Therefore, the construction examination for the bottom part of the low permeable layer by bentonite and the performance check test of the buffer layer were carried out. The result of the construction examination showed that the possibility of the construction were confirmed, and the result of performance check test showed that it was possible to ensure the required performance of the low permeable layer, such as hydraulic conductivity. 